\title{
Onset, development, and cessation of basal Early Triassic microbialites (BETM) in the Nanpanjiang pull-apart Basin, South China Block
}

\author{
Bagherpour, Borhan ; Bucher, Hugo ; Baud, Aymon ; Brosse, Morgane ; Vennemann, Torsten ; Martini,
} Rossana ; Guodun, Kuang

\begin{abstract}
New investigations in the Nanpanjiang Basin indicate that the onset of the iconic microbialites associated with the Paleozoic-Mesozoic boundary was Early Triassic in age. Bathymetry (water agitation, oxygenation, light penetration) and clastic load are shown to have exerted a direct control on the growth of microbialites. Carbonate supersaturation is also required for the deposition of the microbialites. Bathymetric control is further corroborated by the topographic inheritance of a latest Permian pull-apart basin into Early Triassic times, with a distribution of basal Early Triassic microbialites (BETM) restricted to uplifted blocks. This control is also reflected by the accumulation of carbonaceous black shales in adjacent troughs. The geographically most extensive Nanpanjiang BETM bloomed on a large NW-SE trending uplifted block exceeding 12,000 km2 (Luolou Platform) centered on northwestern Guangxi. PostTriassic displacements along the Youjiang Fault obscure the paleogeographic relation of BETM exposed west of this fault. Triassic foraminifers occur in the basal most BETM episode, which is locally bracketed by high-energy grainstones made of reworked Permian foraminifers. Therefore, the Permian-Triassic boundary (PTB) is within the unconformity that separates the Late Permian Heshan Fm. from the basal most BETM. Where accommodation space was sufficient, up to five event surfaces are associated with the unconformity. Microfacies analysis supports chemical dissolution but did not reveal evidence for subaerial erosion, although intercalated grainstone made of Permian foraminifers indicate reworking. Chemical dissolution and mechanical erosion both conceivably contributed to the genesis of the unconformity. The upward shift from tabulated to domical microbial build-ups is accompanied by accumulation of coquinoid lenses between domes, which indicates deepening of the Luolou Platform BETM. The main drowning resulting from both regional tectonic subsidence and a global sea-level rise led to the cessation of the BETM that were buried under predominant fine siliciclastics. Any concomitant change in sea water chemistry appears unlikely.
\end{abstract}

DOI: https://doi.org/10.1016/j.gr.2016.11.013

Posted at the Zurich Open Repository and Archive, University of Zurich

ZORA URL: https://doi.org/10.5167/uzh-129690

Journal Article

Accepted Version

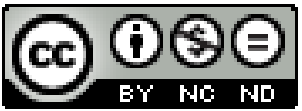

The following work is licensed under a Creative Commons: Attribution-NonCommercial-NoDerivatives 4.0 International (CC BY-NC-ND 4.0) License. 
Originally published at:

Bagherpour, Borhan; Bucher, Hugo; Baud, Aymon; Brosse, Morgane; Vennemann, Torsten; Martini, Rossana; Guodun, Kuang (2017). Onset, development, and cessation of basal Early Triassic microbialites (BETM) in the Nanpanjiang pull-apart Basin, South China Block. Gondwana research, 44:178-204.

DOI: https://doi.org/10.1016/j.gr.2016.11.013 


\section{Accepted Manuscript}

Onset, development, and cessation of basal Early Triassic microbialites (BETM) in the Nanpanjiang pull-apart Basin, South China Block

Borhan Bagherpour, Hugo Bucher, Aymon Baud, Morgane Brosse, Torsten Vennemann, Rossana Martini, Kuang Guodun

PII:

S1342-937X(16)30465-8

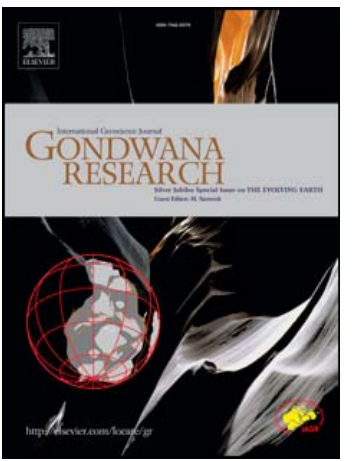

DOI:

doi: 10.1016/j.gr.2016.11.013

Reference:

GR 1724

To appear in: $\quad$ Gondwana Research

Received date: 21 June 2016

Revised date: $\quad 23$ November 2016

Accepted date: $\quad 24$ November 2016

Please cite this article as: Bagherpour, Borhan, Bucher, Hugo, Baud, Aymon, Brosse, Morgane, Vennemann, Torsten, Martini, Rossana, Guodun, Kuang, Onset, development, and cessation of basal Early Triassic microbialites (BETM) in the Nanpanjiang pull-apart Basin, South China Block, Gondwana Research (2016), doi: 10.1016/j.gr.2016.11.013

This is a PDF file of an unedited manuscript that has been accepted for publication. As a service to our customers we are providing this early version of the manuscript. The manuscript will undergo copyediting, typesetting, and review of the resulting proof before it is published in its final form. Please note that during the production process errors may be discovered which could affect the content, and all legal disclaimers that apply to the journal pertain. 
Onset, development, and cessation of basal Early Triassic microbialites (BETM) in the Nanpanjiang pull-apart Basin, South China Block

Borhan Bagherpour $^{\mathrm{a}^{*}}$, Hugo Bucher ${ }^{\mathrm{a}}$, Aymon Baud ${ }^{\mathrm{b}}$, Morgane Brosse ${ }^{\mathrm{a}}$, Torsten Vennemann $^{\mathrm{c}}$, Rossana Martini ${ }^{\mathrm{d}}$, Kuang Guodun ${ }^{\mathrm{e}}$

${ }^{a}$ Paleontological institute, University of Zürich, Karl Schmid-Strasse 4, 8006 Zürich, Switzerland

${ }^{\mathrm{b}}$ BCG Parc de la Rouvraie 28, 1018 Lausanne, Switzerland

${ }^{c}$ Institute of Earth Surface Dynamics, University of Lausanne, Géopolis, 1015 Lausanne, Switzerland

${ }^{\mathrm{d} D e p a r t m e n t ~ o f ~ E a r t h ~ S c i e n c e s, ~ U n i v e r s i t y ~ o f ~ G e n e v a, ~} 13$ rue des Maraîchers, 1205 Geneva, Switzerland

${ }^{\mathrm{e}}$ Guangxi Bureau of Geology and Mineral Resources, Jiangzheng Road 1, 530023 Nanning, China

*Corresponding author: borhan.bagherpour@pim.uzh.ch 


\section{Abstract}

New investigations in the Nanpanjiang Basin indicate that the onset of the iconic microbialites associated with the Paleozoic-Mesozoic boundary was Early Triassic in age. Bathymetry (water agitation, oxygenation, light penetration) and clastic load are shown to have exerted a direct control on the growth of microbialites. Carbonate supersaturation is also required for the deposition of the microbialites. Bathymetric control is further corroborated by the topographic inheritance of a latest Permian pull-apart basin into Early Triassic times, with a distribution of basal Early Triassic microbialites (BETM) restricted to uplifted blocks. This control is also reflected by the accumulation of carbonaceous black shales in adjacent troughs. The geographically most extensive Nanpanjiang BETM bloomed on a large NW-SE trending uplifted block exceeding $12000 \mathrm{~km}^{2}$ (Luolou Platform) centered on northwestern Guangxi. Post-Triassic displacements along the Youjiang Fault obscure the paleogeographic relation of BETM exposed west of this fault.

Triassic foraminifers occur in the basal most BETM episode, which is locally bracketed by high-energy grainstones made of reworked Permian foraminifers. Therefore, the Permian-Triassic boundary (PTB) is within the unconformity that separates the Late Permian Heshan Fm. from the basal most BETM. Where accommodation space was sufficient, up to five event surfaces are associated with the unconformity. Microfacies analysis supports chemical dissolution but 
did not reveal evidence for subaerial erosion, although intercalated grainstone made of Permian foraminifers indicate reworking. Chemical dissolution and mechanical erosion both conceivably contributed to the genesis of the unconformity. The upward shift from tabulated to domical microbial build-ups is accompanied by accumulation of coquinoid lenses between domes, which indicates deepening of the Luolou Platform BETM. The main drowning resulting from both regional tectonic subsidence and a global sea-level rise led to the cessation of the BETM that were buried under predominant fine siliciclastics. Any concomitant change in sea water chemistry appears unlikely. Keywords: Permian-Triassic boundary; Microbialites; Bathymetry; Oxygen; Alkalinity. 


\section{Introduction}

The widespread deposition of microbial limestone in equatorial shallow seas is a hallmark of the Permian-Triassic transition. Deposition of the microbial limestone is intimately related to the largest mass-extinction of the Phanerozoic (Raup, 1979; Sepkoski, 1984), which occurred just before the Permian-Triassic transition between $251.941 \pm 0.037$ and $251.880 \pm 0.031 \mathrm{Ma}$ (Burgess et al., 2014). In equatorial shallow waters, the Late Permian skeletal carbonate production was ended with a global regression coinciding with the PTB (Yin et al., 2014) and was replaced by the production of microbialites during the earliest Early Triassic (BETM) (e.g. Lehrmann et al., 2003; Lehrmann et al., 2015a). Although microbialite deposits are recurrent during Early Triassic times (e.g. Lehrmann, 1999; Baud et al., 2007; Brayard et al., 2011), their abundance typically peaked during the Griesbachian (basal Early Triassic), as exemplified by records from the South China Block (Lehrmann et al., 2003; Ezaki et al., 2008; Yang et al., 2011; Jiang et al., 2014),Turkey (Baud et al., 1997, 2005) and Iran (Taraz et al., 1981; Kozur et al., 2005, 2007; Baud et al., 2007; Richoz et al., 2010; Leda et al., 2014). The BETM have a distinctive equatorial distribution, and have been commonly interpreted as devastated ecosystems (Awramik, 1990; Schubert and Bottjer, 1992) and/or anachronistic facies reminiscent of Precambrian or Early Paleozoic shallow water microbedominated biota (Sepkoski et al., 1991; Baud et al., 1997, 2002, 2007; Kershaw 
et al., 1999, 2007; Pruss et al., 2006; Ezaki et al., 2008). The resurgence of microbe-dominated shallow-water environments has been tentatively explained by a temporary absence of predation pressure from grazing metazoans that were removed by the Permian-Triassic mass extinction (Schubert and Bottjer, 1992; Lehrmann, 1999; Pruss et al., 2006). Alternative explanations include ocean carbonate supersaturation, as well as upwelling of alkaline waters from deeper oxygen-depleted water masses within the intertropical convergence zone (Kershaw et al., 1999, 2007). Subsequently, Kershaw et al. (2012a) downplayed their earlier interpretations about upwelling and emphasized the importance of relative sea-level changes and clastic input as local controls on the formation of BETM for sections mainly located on the northern edge of the South China Block. Lehrmann et al. (2015a) also interpreted a lack of thickening of the microbialite unit towards platform margins as evidence against an upwelling of anoxic alkaline waters.

A detailed investigation of onset, development, and cessation of the BETM may improve the understanding of the underlying processes that fostered the deposition of microbial limestone. The distinction between global and local factors that enabled or impeded the deposition of microbialites is crucial for distinguishing the various processes that may have been at play. The South China Block offers the largest concentration of sections across the BETM and the Nanpanjiang Basin in the present-day southern part of the block includes many such well-exposed sections. The new data from the Nanpanjiang Basin 
presented in this paper add to the results from previous studies of the BETM (Lehrmann et al., 2003; Ezaki et al., 2008; Kershaw et al., 2011; Yang et al., 2011; Deng et al., 2016) and newly integrate observations from a broad range of scales, from micro-textures to basin geodynamic regime. Special emphasis is also placed on the cessation of microbialites deposition.

The nature of the unconformable boundary between the Late Permian skeletal limestone and the BETM is a matter of diverging interpretations. In South China, Payne et al. (2007), Song et al. (2009a) and Lehrmann et al. (2015a) interpreted the truncation of Upper Permian limestone as a submarine chemical dissolution surface resulting from acidification of the upper water column. Alternatively, the same surface was interpreted as the result of subaerial erosion by Liu et al. (2007), Collin et al. (2009) and Wignall et al. (2009). As reviewed by Yin et al. (2014), both processes are not mutually exclusive and their expression in the rock record may vary laterally as a function of uneven paleotopography and accommodation space. However, diagenetic microfabrics observed in thin sections in support of subaerial erosion by Liu et al. (2007), Collin et al. (2009) and Wignall et al. (2009) were subsequently questioned by Lehrmann et al. (2015a). The duration of the hiatus separating the Late Permian skeletal limestone from the Early Triassic microbialites is also unknown. Payne et al. (2007) argued that "the contact between skeletal packstone and microbialite in south China... is biostratigraphically complete, suggesting that erosion did not remove a substantial thickness of sediment or corresponding 
time". On the basis of a previous calibration of conodont interval zones assumed to be of equal duration and calibrated against supposed astronomical cycles in the Germanic Basin, Yin et al. (2014) proposed a duration of ca. 50100 ky for the unconformity between latest Permian skeletal limestone and earliest Triassic microbialites they assigned to the latest Clarkina yini to $C$. meishanensis-Hindeodus changxingensis interval zones in Meishan.

Comparisons of the detailed facies evolution that can be extracted from the BETM may also contribute to distinguish between local and global controls. Both shallowing and deepening trends have been inferred from facies analysis of various BETM sections (e.g. Ezaki et al., 2003; Kershaw et al., 2011; Deng et al., 2016). Comparisons within and across different Tethyan equatorial transit blocks (Ricou, 1994), such as South China and Turkey, may also help extracting the commonalities and differences of BETM sections, provided that enough information is available for reconstructing the paleogeographic and geodynamic context in which they were deposited. Similarly, patterns of cessation of the BETM may shed light on the relative roles of global versus local controls. Two diverging interpretations have been proposed, with either an abrupt (Kershaw et al., 2002; Ezaki et al., 2003; Deng et al., 2016) or a step-wise cessation (Ezaki et al., 2008).

In this study, the BETM is compared from seven different sections of the northwestern Guangxi part of the Nanpanjiang Basin in the South China Block. These results are then discussed in the larger context of the South China Block 
and of other Tethyan transit blocks such as Turkey. In order to gain a better understanding of the BETM within the Nanpanjiang Basin, this work focusses on: i) sedimentary features and facies analyses of the transition between Late Permian skeletal carbonates and the BETM; ii) the development and formation of different types of microbialites; and iii) the cessation of microbialites deposition. Robust conodont age constraints are only available for the upper part of the BETM (Brosse et al., 2016a) and are also utilized for assessing the timing of cessation. The BETM is further considered in the Early Triassic paleogeographic and geodynamic context of the Nanpanjiang Basin, a scale that is also required for screening among paleoceanographic hypotheses. Finally, a comparison with other low-paleolatitude basal Early Triassic records can clarify the role of paleogeography and associated paleoceanographic aspects for the production of the BETM.

\section{Paleogeographic setting}

During the Late Permian and Early Triassic, the Nanpanjiang Basin (Fig. 1a) evolved as a pull-apart basin in a back-arc context (HB ongoing work), resulting from the oblique convergence between the Indochina and South China blocks. The related volcanic Lang Son Arc is exposed in a belt near the presentday Vietnam-Guangxi border (Thanh et al., 2014; Halpin et al., 2016). Further to the southwest, the Song Chay ophiolite-bearing suture represents the 
convergence zone between the South Chinese upper plate and the Indochinese lower plate (Faure et al., 2016). As we consistently observe in the Nanpanjiang Basin, the basal Early Triassic (Griesbachian) paleotopography is typically inherited from the latest Permian one, thus indicating a permanent and similar regional geodynamic control of the basin across the Permian-Triassic Boundary (HB, ongoing work). Our field data indicate that occurrences of the BETM are strictly restricted to sections where the latest Permian is represented by shallowwater facies (essentially skeletal packstones). In the Nanpanjiang Basin, the northwest Guangxi-south Guizhou BETM platform exceeds a $12000 \mathrm{~km}^{2}$ surface area that precisely matches with the extent of the underlying latest Permian shallow-water carbonate rocks (Fig. 1b). This large and laterally continuous BETM platform, here named the Luolou Platform, includes the following areas: southwestern part of Donglan County, most of Fengshan, Leye, and Lingyun counties, northwestern part of Bama County (all northwestern Guangxi), and southern Wangmo County (southern Guizhou). In all these areas, the BETM represents the lowermost and shallowest part of the Luolou Formation, which otherwise encompasses younger and deeper water facies representing outer platform settings (Galfetti et al., 2008). Yet, how the BETM of the Pingguo area paleogeographically relates to the Luolou Platform to the northwest is uncertain. It was interpreted as an isolated platform by Lehrmann et al. (2007a), but it more probably represents the southern tip of the Luolou BETM platform, just east of the Youjiang Fault. The BETM in Pingguo County 
occurs at the base of the Majiaoling Formation (Fig. 1, Supplementary material), which is essentially an upper slope lateral equivalent of the outer platform Luolou Fm. East of the Youjiang Fault, the distribution of late Permian and Early Triassic depositional environments in the Wangmo area and northwestern Guangxi delineates a clear NW-SE orientation of depositional environments distinguished by contrasted bathymetry (Fig. 1b). We observe that the main structural phase of the basin took place during the deposition of the upper part of the Late Permian Wujiaping Fm., as indicated by intercalated kilometric wedges of breccia along the Donglan Fault that demarcates the eastern edge of the Luolou Platform (Fig. 1b). This structural configuration governed the subsequent lateral and coeval deposition of the Heshan Fm. on horsts and of the Dalong Fm. in grabens during the Changhsingian (Fig. 1, Supplementary material). The eastern edge of the Luolou Platform typically runs along a NW-SE line that passes near Donglan. The deepest facies of the Dalong Fm. are represented by radiolarian cherts immediately east of the Donglan Fault, suggesting a depth contrast $>10^{3} \mathrm{~m}$ with the Heshan Fm. to the west. Hence, the Luolou Platform on which the BETM bloomed obviously extends far back into the late Permian. Unlike the Youjiang Fault, the Donglan Fault was not reactivated in post-Triassic times and allows a robust paleogeographic reconstruction which is at variance with previous models of isolated small platforms. In the southwestern part of the Nanpanjiang Basin, the paleogeographic position of the BETM of the Chongzuo, Debao and Jinxi 
platforms (Lehrmann et al., 2007b; Algeo et al., 2007) is difficult to restore with respect to the Luolou Platform because of substantial post-Triassic displacements along of the Youjiang Fault as well as in western part of the basin. These displacements have been omitted in previous reconstructions (e.g. Lehrmann et al., 2015a). Further north, a smaller tilted horst (ca. $2000 \mathrm{~km}^{2}$ ), christened the "Great Bank of Guizhou" (GBG) by Lehrmann et al. (e.g. 1998 and 2007a), displays an exceptionally long-lived (Late Permian to Late Triassic) shallow-water carbonate succession that includes the BETM episode (Li et al., 2012). This misleading labelling that alludes to present-day carbonate banks has been recently criticized by Feng et al. (2015), who recommended using a more realistic appellation such as the "Luodian Carbonate Platform". All these tectonic highs with shallow water BETM were laterally limited by slope and basinal deposits in Guangxi and southern Guizhou (Fig. 1b). The role of regional tectonics and of the broader geodynamic frame in the spatial distribution of the BETM in the Nanpanjiang Basin has therefore been commonly overlooked. Primary control has customarily been placed on biological calcification that was considered to be the main controlling agent involved in the construction of carbonate "low-relief banks" during the Early Triassic (e.g. Lehrmann et al., 2003). Moreover, bearing in mind that the studied sections were deposited in a pull-apart basin also puts further limitation on the intensity of water mass exchanges with the open ocean. The isolated "low-relief banks" model during the deposition of the BETM and later Early Triassic times 
(Lehrmann et al., 2003) was subsequently emended by adding isolated "drowned Upper Permian-basal Triassic platforms" in northwestern Guangxi (Lehrmann et al., 2015a, Fig. 1). However, the lateral continuity shown by the BETM within a single and much larger shallow-water platform (namely the Luolou Platform) was also ignored. Occasional and more or less coeval deposition of black shales or oxygen-poor sediments on Griesbachian shelves are generally assumed to represent an expansion of the oxygen minimum zone brought about by a global sea-level rise (Wignall and Hallam, 1993). However, the depth of the oxygen minimum zone in a silled basin such as the Nanpanjiang may be unrelated to global sea-level changes and may only reflect weak local circulation. Moreover, the absence of any anoxia during Griesbachian time on Tethyan off shore sea-mounts (Krystyn et al., 2003; Baud et al., 2014; Brosse et al., 2016b), on the northern Indian Margin (Hermann et al., 2011; SchneebeliHermann et al., 2013) and in the NE Greenland rift (Sanson-Barrera et al., 2015) notably undermine the mantra of a global expansion of the oxygen minimum zone at that time. The partly coeval deposition of black shales in troughs adjacent to these tectonic highs, is better assigned to a local and stable stratification of the water column, rather than to any equivocal global rise of the oxygen minimum zone. Circulation between the Nanpanjiang Basin and the open ocean was essentially surficial, the intervening volcanic Lang Song Arc and silled topography of the Nanpanjiang back-arc basin precluding efficient mixing of deeper water masses. The general setting of the Nanpanjiang BETM 
advocated here is that of tectonic troughs with restricted circulation separated by horsts reaching above fair-weather wave-base depth, which permitted the BETM to thrive in clastic-free and oxygenated waters. This paleotopographic setting is diagnostic of a pull-apart basin, whose structuration initiated in the late Permian and which ended near the Early-Middle Triassic boundary (Galfetti et al., 2008; Ovtcharova et al., 2015), with a drastic change from a transtensional to a compressional regime manifested by the deposition of several kilometers of siliciclastic turbidites. Within the Luolou Platform, the new BETM sections studied here include Wuzhuan, Nanem, Longyuan, Youping, Tienbao, and Shanmenhai. In the Pingguo area, the Taiping section (Lehrmann et al., 2003) is also re-investigated (Figs. 2, 3 and 4).

\section{Age and duration of the microbialites}

The accuracy of conodont age control in microbialites and elsewhere depends on two criteria: a) the quality and density of the faunal record (i.e. the combined effects of sampling effort and ecological control on occurrence of taxa) and b) the method used to build biochronozones. A recent and comprehensive study of the basal Triassic conodont faunas from South China highlighted inconsistencies inherent to interval zones and proposed a robust and reliable zonation based on a revised taxonomic data set and the utilization of Unitary Association Zones (Brosse et al., 2016a, 2016c), which is followed 
here. This work also pointed out the diachronous first local occurrence (FO) of Hindeodus parvus (the index species of the first Triassic interval zone) within the microbialites. One of the absurd consequences of the utilization of the diachronous FO of $H$. parvus as a base Triassic index is that despite the absence of Permian taxa, the base of the BETM is often assigned a default Permian age (e.g. Xie et al., 2010), only because age-diagnostic conodonts have not been recovered from the microbialites underlying a delayed FO of $H$. parvus. The frequent lack of age-diagnostic conodonts in the base of the microbialites is no indication of a Permian age.

The Permian-Triassic biochronological boundary falls within the interval of separation between the conodont UAZ2 and UAZ3 as defined by Brosse et al. (2016a) in the more fossiliferous record of Meishan. The second Triassic UA zone, UAZ4, was identified by Brosse et al. (2016a) at the very base of the microbial limestone at Dajiang in the GBG, thus indicating that the gap observed at the base of this lithological unit ranges well into the Early Triassic. Additionally, the youngest Permian UA zone, UAZ2, was identified at the very top of the Permian skeletal limestone in the nearby Dawen section. The unconformity separating the Permian skeletal limestone and the Early Triassic microbial limestone thus includes UAZ3 in the Dajiang-Dawen area. Hence, any previous statement of absence of biochronologic gap at the base of microbialites is unsound. UA zone correlations (Brosse et al., 2016a) with Meishan and its $\mathrm{U}-\mathrm{Pb}$ age calibration indicated that the time interval between 
UAZ2 and UAZ4 is $61 \pm 48 \mathrm{ky}$. Hence, the hiatus in Dajiang-Dawen precisely corresponds to the timing of the extinction interval in Meishan (Burgess et al., 2014).Therefore, the base of the microbialites in the sections described here must be assigned a Triassic age, as independently indicated by the presence of Triassic foraminifers and the carbon isotope record. As shown by Brosse et al. (2016a), the top of the microbial limestone falls within UAZ5 at Wuzhuan and is below UAZ6 at Dajiang and Dawen. This leaves the question of the synchronicity or diachronism of the cessation of the microbial limestone unanswered at this stage. Using an actualistic approach based on the growth rate of marine stromatolite, Hautmann et al. (2015) estimated a minimum duration of 25-30 ky for the ca. $9.5 \mathrm{~m}$-thick microbial limestone in Wuzhuan. New high resolution $\mathrm{U}-\mathrm{Pb}$ age dates (Baresel et al., in revision) obtained for the youngest preserved Permian bed, which is an ash layer in many PTB sections of the Luolou Platform, and for the laterally widely distributed volcanogenic greywacke overlying the BETM, indicate a duration of $\sim 110 \pm 130$ ky for the interval comprising the PTB unconformity and the BETM in the Nanpanjiang Basin. Subtracting the $61 \pm 48$ ky long interval obtained for the unconformity in the Dajiang-Dawen area, the duration of the BETM then amounts to $49 \pm 178$ ky. Hence, the order of magnitude of the growth rate of the BETM in our sections is close to $0.2 \mathrm{mmy}^{-1}$, a value which is in perfect agreement with the known maximum of $0.4 \mathrm{mmy}^{-1}$ for living stromatolite in Shark Bay (Chivas et 
al., 1990). Assuming a constant growth rate, the thickest (12m) BETM documented here from Shanmenhai would span a time interval of $\sim 60 \mathrm{ky}$.

\section{Material and methods}

Sections were logged and sampled bed by bed in the field and were sampled for the preparation of 30 polished slabs and 120 thin sections for further within-bed details. Using a Leica M165C microscope, petrographic classification of the skeletal limestone samples is based on Dunham, (1962) classification system. Grainstones close to the PTB were studied under cathodoluminescence microscopy (CL) for detecting successive potential diagenetic phases and preservation state of skeleton microstructures. CL analyses were completed with an ERI-MRTech-optical cathodoluminescence microscope with a cold cathode that was mounted on an Olympus BX41 petrological microscope. The beam conditions were $18 \mathrm{kV}$ at $120-200$ microA with an unfocused beam of approximately $1 \mathrm{~cm}$. The observation chamber has a residual pressure of about 80 mTorr. The samples were not coated. For the microbialites, we follow the classification and the four scales of observation of fabrics (1-mega-, 2- macro-, 3- meso-, and 4- microstructure) given by Shapiro (2000). This author defined: 1- megastructures as large-scale landscapes of microbialites (e.g., biohermal or biostromal buildups), 2macrostructures as growth form of the microbialites ranging from tens of 
centimeters to a few meters (e.g. tabular, columnar or domes), 3- mesostructures as internal textures of macrostructural elements, which are visible to the naked eye (e.g., clotted, dendritic or digitated), and 4- microstructures as fabrics observed under the microscope. In this classification, three types of mesostructures can be distinguished: laminated (stromatolites), clotted (thrombolites) and dendritic (dendrolites) (see also Riding, 2000, 2005, 2011 for further details).

High-resolution sampling was carried out in the Wuzhuan and Tienbao (Fig. 1b, $2,3)$ sections for stable isotope measurements $(\mathrm{C}$ and $\mathrm{O})$ of bulk micrite $\left(\delta^{13} \mathrm{C}_{\text {carb }}, \delta^{18} \mathrm{O}_{\text {carb }}\right)$. Samples were carefully cleaned, cut and drilled with a diamond-tipped drill to produce a fine powder. The C-and O- isotope composition of the carbonates were measured with a GasBench II connected to a Finnigan MAT DeltaPlus XL mass spectrometer, using a He-carrier gas system according to a method adapted after Spötl and Vennemann, (2003). For calcite samples, a reaction temperature of $70{ }^{\circ} \mathrm{C}$ is used and samples are reacted for 1 hour. In-house standards of calcite are treated in the same way run interspersed with the samples in the same sequence. Samples are normalized using our in-house Carrara Marble standard calibrated against $\delta^{13} \mathrm{C}$ and $\delta^{18} \mathrm{O}$ values of NBS-19 (+1.95 and $-2.20 \%$, relative to VPDB). External reproducibility for the analyses estimated from replicate analyses of the inhouse standard ( $\mathrm{n}=8$ per run) was better than $\pm 0.08 \%$ for $\delta^{13} \mathrm{C}$ and $\pm 0.1 \%$ for $\delta^{18} \mathrm{O}$ values. 


\section{Results}

The Permian-Triassic boundary (PTB) in all studied sections is included in a hiatus marked by the abrupt facies change that characterizes the boundary between the Heshan and the Luolou formations. It is associated with a change in the $\delta^{13} \mathrm{C}_{\text {carb }}$ values by about 1 per mil towards lower values (Fig. 2 and 3). The first local occurrences of the index conodont Hindeodus parvus in the Nanpanjiang Basin are known to be diachronous (Zhang et al., 2014; Brosse et al., 2015, 2016a, 2016c, see Figs. 2 and 3) and to largely postdate the base of the Triassic in many BETM sections. For the Wuzhuan section, the reader is referred to Brosse et al. (2015) for thorough information on the stratigraphic succession of conodonts and to Hautmann et al. (2015) for the diversified benthic molluscan fauna and its ecological significance. Other sections have only limited information on conodont occurrences. High-resolution $\delta^{13} \mathrm{C}_{\text {carb }}$ data are given here for Wuzhuan and Tienbao (Table 1, Supplementary material). Cisotope data are also available for Taiping (Krull et al., 2004; Luo et al., 2014a; Lehrmann et al., 2015a).

Thin sections studied under CL indicate that all carbonate rocks have been uniformly overprinted by a late diagenetic phase that erased the earlier diagenetic history. This late phase includes the growth of microcrystalline dolomite rhombs. However, in some cases, it is possible to reconstruct part of the early diagenetic history. 


\subsection{Wuzhuan}

This section $\left(24^{\circ} 21^{\prime} 44.6^{\prime \prime} \mathrm{N} ; 107^{\circ} 20^{\prime} 02.00^{\prime \prime} \mathrm{E}\right)$ is located south-east of Fengshan (No. 1 in Fig. 1b). The shallow-water limestone of the Permian Heshan Formation is characterized by medium to thick $(20-100 \mathrm{~cm})$ wackestone beds (intercalated occasionally with packstone beds) rich in diagenetic chert nodules and interbedded with numerous ash layers (Figs. 2, 4a). These limestones are rich in shallow marine benthic fauna represented by corals, crinoids, brachiopods, bryozoans, fusulinids and small foraminifers.

The boundary between the Heshan (Unit 1) and Luolou formations at Wuzhuan (Fig. 5) immediately overlies a $12 \mathrm{~cm}$-thick ash layer (Unit 2, Fig. 5a). Five Event Surfaces (ES1-5) are recognized between the youngest limestone bed of the Heshan Fm. and the main body of the microbial limestone. The first Event Surface (ES1) is an irregular contact between limestone of the Heshan Fm. and the last Permian ash layer. The second Event Surface (ES2) separates the top of the ash layer from the basal calcarenite bed (Unit 3, Fig. 5b) of the Luolou Fm., which is a bioclastic grainstone containing abundant foraminifers of exclusively Late Permian age (Rectostipulina quadrata JennyDeshusses, 1985; R. pentamerata Groves, Altiner and Rettori, 2005; Dagmarita chanakchiensis Reitlinger, 1965; Louisettita ?elegantissima Altiner and Bronnimann, 1980; Dagmarita sp.; Ichthyofrondina cf. I. palmata (Wang, 1974); Ichthyofrondina sp.; Paraglobivalvulinoides septulifer (Zaninetti and 
Altiner, 1981); Nankinella sp.; Globivalvulina sp.; Climacammina sp.;

Glomomidiella sp.; ?Midiella sp.). Thin sections reveal that bioclasts were first coated by marine radiaxial fibrous cement (Fig. 6a, b and c). The habitus of these crystals suggests that this early phase consisted of aragonitic cement that formed prior to any compaction of the bioclasts whose original shape is preserved. Such aragonitic fibrous cement is known to develop in the upper intertidal to supra-tidal zone (Bartley et al., 2000). A second phase is represented by the filling of the remaining space between the coated bioclasts by blocky calcite (Fig. $6 \mathrm{~b}$ and c). A third and late phase includes the development of stylolites (Fig. 6d), of tiny dolomite rhombs and an almost general recrystallization of the carbonate as highlighted by CL (Fig. 6e and f). The basal calcarenite (Unit 3) is separated from the first overlying clotted microbialites ( $8 \mathrm{~cm}$ thick, Unit 4 ) by a very thin lenticular clay bed and an irregular truncation surface (ES3). The interstitial micrite of Unit 4 yielded the Triassic foraminifers Globivalvulina sp. and ?Cornuspira mahajeri Brönnimann, Zaninetti and Bozorgnia, 1972 (= Postcladella kahlori n. comb. Krainer and Vachard, 2011). The uneven upper surface of this bed (ES4, Fig. 5c) is overlain by a 6-7 cm-thick packstone (Unit 5, Fig. 5d) containing superficial ooids and foraminifers exclusively of Late Permian age (Dagmarita chanakchiensis Reitlinger, 1965; Globivalvulina vonderschmitti, Reichel, 1946; Ichthyofrondina sp.; ?Nankinella sp.; Paraglobivalvulina mira Reitlinger, 1965; Paraglobivalvulinoides septulifer (Zaninetti and Altiner 1981). The occurrence 
of Triassic foraminifers in Unit 4 suggests that all Permian foraminifers found in Unit 5 were reworked. Another alternative scenario is that Late Permian foraminifers from Unit 5 are survivors of the first phase of foraminiferal extinction as advocated by Song et al. (2009a, 2009b). However, the faunal compositions of Units 3 and 5 unambiguously reflect pre-extinction assemblages, thus supporting the reworking interpretation. The overlying main microbialite body (Unit 6b) is separated from this second grainstone bed (Unit 5) by an irregular truncation surface (ES5).

The main microbialite unit (Unit 6b) displays tabular constructions with a clotted fabric (thrombolite) in its lower half and domical buildups with a digitate (dendrolite) fabric in its upper half (Figs. 2 and 7b). In tabular thrombolites, centimetric and isolated mesoclots made of sparitic masses are embedded in a micritic matrix. These sparitic masses have an irregularly indented outline without any preferred orientation (Figs. 8a, b and 9a). This spotted texture is the main texture of the tabular thrombolite. Domical dendrolites, centimetric digitate mesoclots embedded in a micritic groundmass display a distinctive vertical to radial orientation. These digitate mesoclots are separated from the micritic groundmass by a sharp and regular outline. No spheroidal elements or coccoid structures were recognized in the digitate mesoclots. A large portion of these sparitic mesoclots is also dolomitized. Observed dolomite rhombs in this thrombolites are of secondary origin and probably formed during the late diagenetic overprint mentioned earlier. The 
interstitial micrite between the digitate mesoclots yielded small gastropods and Cornuspira sp. (Fig. 9f), the latter being reported from other basal Early Triassic microbialites in South China by Song et al. (2015) and Yang et al. (2011).

Shelly lenses with mainly packstone-grainstone textures occur between the domical microbialites (Figs. 2 and $7 \mathrm{~b}$ ). These coquinoid lenses contain highly diverse and abundant bivalves and subordinate brachiopods and gastropods (Hautmann et al., 2015). Similar lenses reported from other BETM sections (Shanggan) in the Luolou Platform (3 km north of Leye in Fig. 1b) also contain abundant and diverse bivalves (Hautmann et al., 2011), gastropods (Kaim et al., 2010), conodonts (Brosse et al., 2015), and occasional ammonoids (Brühwiler et al., 2008). It is worth noting that ostracods and echinoderm ossicles also occur in these lenses (Hautmann et al., 2015). The intraskeletal or shelter cavities of bivalves and gastropods are occasionally filled with peloids, micrite, and geopetal structures. Such peloids have been related to bacterial activities (Adachi et al., 2004).

The top of the microbialites Unit $6 \mathrm{~b}$ is capped by thin-bedded bioclastic wackestone beds yielding sparse small-sized gastropods, thin-shelled bivalves, and occasional ostracods. This unit is overlain by a $50 \mathrm{~cm}$-thick volcanogenic greywacke bed (Unit 7, Fig. 2). The greywacke interval is in turn overlain by brown-weathering carbonaceous, black, laminated mudstones intercalated with medium grey wackestone beds (Unit 8, Fig. 2). 
The high-resolution $\delta^{13} \mathrm{C}_{\text {carb }}$ record from the Wuzhuan section can be divided into three different stages (Fig. 2). The Late Permian Heshan Fm. has positive $\delta^{13} \mathrm{C}_{\text {carb }}$ values with substantial fluctuations superimposed onto a protracted negative shift of $2 \%$ (from ca. $4.5 \%$ to $2.5 \%$ ). This first phase ends with an abrupt decrease of 1\%o around the first grainstone (Unit 3) at the base of the Luolou Fm. In addition to the significance of the detailed facies changes described above, this negative jump of $1 \%$ is an additional indication of a stratigraphic gap. The second phase shows a short negative shift from ca. 1.5 to $0 \%$ spanning Units 4, 5, and the first two meters of Unit 6 . The third phase is characterized by a steady state with $\delta^{13} \mathrm{C}_{\text {carb }}$ values around $0 \%$. The $\delta^{18} \mathrm{O}_{\text {carb }}$ values are ranging from $-5 \%$ to $-12 \%$ in the Heshan Fm. and display a stable plateau near $-6 \%$ in the microbialite unit (Table 1 , supplementary material). Although an anomaly in $\delta^{18} \mathrm{O}_{\text {carb }}$ (with no correlative change in $\delta^{18} \mathrm{C}_{\text {carb }}$ ) around a thick volcanic ash layer in Heshan Fm. is observed, no correlation between carbon and oxygen isotope values that would suggest a diagenetic overprinted on $\delta^{13} \mathrm{C}_{\text {carb }}$ can be detected.

\subsection{Nanem}

The Nanem section $\left(24^{\circ} 24^{\prime} 02.8^{\prime \prime} \mathrm{N} ; 107^{\circ} 19^{\prime} 28.1^{\prime \prime} \mathrm{E}\right)$ is located $4 \mathrm{~km}$ north of the Wuzhuan section (No. 2 in Figs. 1b, 4b) and the lithological succession is very similar to that of Wuzhuan (Fig. 2). The contact between the limestones 
(Unit 1) and the last ash layer (Unit 2) of the Permian Heshan Fm. is an irregular surface (ES1). The topmost ash layer is overlain by a basal calcarenite, which is here a thin bioclastic packstone-wackestone limestone bed (Unit 3, Fig. 10a, b). This calcarenite is overlain by a first episode of the microbial limestone, which is represented by a $6 \mathrm{~cm}$-thick stromatolite (Unit 4, see Figs. 10b, 11a, b, c) containing millimetric carbonate crystal fans (Fig12a). The interstitial micrite between stromatolite columns (decimetric domes) contains the Triassic Cornuspira sp. The contact between the basal calcarenite (Unit 3) and the thin stromatolite bed (Unit 4) is an irregular truncation surface (ES3) underlined by a crust of iron oxide (Fig. 11a). The upper boundary of the stromatolite bed is also an irregular truncation surface (ES4), which is overlain by a superficial ooid grainstone bed (Unit 5, Figs. 10b and 12b, c). The main microbialite body (Unit $6 b$ ) is again separated from the ooid grainstone (Unit 5) by an irregular truncation surface (ES5).

The lower part of the main microbialites (Unit 6b) exhibits tabular forms of thrombolite with common spotted texture while the upper part displays domes (Fig. 7d) associated with a predominant digitate fabric. Shelly lenses are intercalated between the domes in the upper part of Unit 6b. At Nanem, the volcanogenic greywacke (Unit 7) directly overlies the microbial limestone and is in turn followed by back laminated mudstones intercalated with medium (20$30 \mathrm{~cm}$ ) grey wackestone beds (Unit 8). 


\subsection{Tienbao}

This section is located north-west of Leye, in the northwestern part of

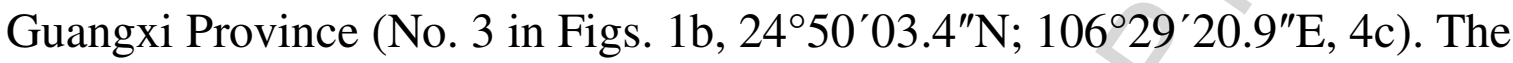
Permian Heshan Fm. consists of medium- to thick-bedded $(20-100 \mathrm{~cm})$ limestone with dark chert nodules and intercalated ash layers. The Heshan Fm. displays a wackestone-packstone microfacies and contains a rich benthic fauna including brachiopods, bivalves, corals, sponges, algae, and foraminifers (Unit 1). It is separated from a $10 \mathrm{~cm}$-thick ash layer by an irregular surface (ES1; Fig. 13).

The topmost layer of the Heshan Fm. is again an ash layer (Unit 2) that ends with ES2. It is then overlain by an $8 \mathrm{~cm}$-thick calcarenite (Unit 3, Fig. 13), corresponding to a packstone with fragmented skeletal grains including bivalves, gastropods, bryozoans, green algae and foraminifers (Fig. 11g) (Paraglobivalvulina mira Reitlinger, 1965; Pseudovermiporella sodalica Elliott, 1958; Nodosinelloides sp.; Dagmarita sp.; Climacammina sp.; ?Deckerella sp.; Palaeotextularia sp.; Eotuberitina sp.; Ichthyofrondina sp.) of Permian age. Above Unit 3, ES3 and 4 cannot be distinguished and are probably amalgamated with ES5. The main microbialite body (Unit 6) is thus resting on an undulating truncation surface (ES3-5) that cuts through calcarenite grains and groundmass of Unit 3 (Figs. 11g, h, i). Thin sections and polished slabs reveal evidence of bioerosion as well as abundant iron oxide lining the 
truncation of the amalgamated surface ES3-5. Burrows are filled with sparry calcite and the positive reliefs are encrusted with stromatolites containing disseminated pyrite crystals (Figs. 11g, h, i). The interstitial sediment between stromatolite columns contains millimetric carbonate crystal fans with a micritized envelope, gastropods, foraminifers, echinoid spines and unidentified bioclasts (Fig. 12d).

The microbialite body (Unit 6) is 3.5 m thick only. The base of the microbialites shows a thin $(4 \mathrm{~cm})$, discontinuous but distinctive stromatolite layer (Unit 6a) (Figs. 11g, 13). The contact between stromatolite crusts of Unit 6a and the overlying thrombolites (Unit $6 \mathrm{~b}$ ) is conformable, without any signs of an erosional surface.

The main part of the microbialites (Unit $6 \mathrm{~b}$ ) consists of tabular clotted thrombolites with spotted texture followed by domical digitate dendrolites (Figs. 4c, 7a, 14). The FO of H. parvus is $1.8 \mathrm{~m}$ above the base Unit 6 .

The uppermost domical digitate dendrolites of Unit $6 \mathrm{~b}$ are overlain by ca. $1 \mathrm{~m}$ of thin-bedded wackestone (Fig. 14c, d). Twenty-five centimeters above the base of the wackestone, a thin greywacke (Unit 7) is intercalated. The vertical growth of the topmost dendrolites was largely controlled by the variable ratio between sedimentation rate and growth rate as shown in Figure 14d. Cessation of the microbialites in Tienbao clearly resulted from rapid burial of the digitate dendrolites by increased fluxes of shaly micritic limestone. The locally expanded record immediately following the microbial limestone shows that the 
ubiquitous volcanogenic greywacke (Unit 7) is in fact included within mudstone-wackestone limestone (Fig. 3), as is also the case in Wuzhuan (Fig. 2). In Tienbao, the greywacke has a reduced thickness of ca. $20 \mathrm{~cm}$ and yields poorly preserved bivalves of several centimeters in shell length, thus contrasting with the much smaller size of bivalves specimens observed in the older coquinoid lenses intercalated between the microbial domes. The next overlying volcanic ash layer is in turn followed by an at least $12 \mathrm{~m}$-thick, dark grey to black, laminated calcareous mudstone unit containing abundant specimens of Claraia sp. indet. (top of Unit 8).

The $\delta^{13} \mathrm{C}_{\text {carb }}$ record in this section also shows a change in values from 3.5 to 1.5 \%o with relatively large superimposed fluctuations in the Heshan Fm. In the base of the Luolou Fm., a negative jump of $1.5 \%$ is again observed in the basal calcarenite, which is in turn followed by a gradual negative shift in the first 0.8 $\mathrm{m}$ of the microbial limestone. Up-section, the $\delta^{13} \mathrm{C}_{\text {carb }}$ isotopic values reach a 0 $\%$ plateau extending throughout the rest of the microbialite unit. The $\delta^{13} \mathrm{C}_{\text {carb }}$ record of Tienbao is in perfect agreement with that of Wuzhuan (compare Figs. 2 and 3). In addition, it demonstrates that the $0 \%$ plateau extends further up section into the shaly micritic limestone blanketing the BETM, thus recording that the cessation of the microbialites deposition is unrelated to any isotopic change of the regional carbonate carbon reservoir. Almost all $\delta^{18} \mathrm{O}_{\text {carb }}$ values are between $-5 \%$ and $-9 \%$ and no correlation between carbon and oxygen isotope 
values can be detected (Table 1 , supplementary material). Hence $\delta^{13} \mathrm{C}_{\text {carb }}$ values are most likely unaffected by diagenetic overprint.

\subsection{Youping}

The Youping section is located north of Leye, in the northern part of the Guangxi Province $\left(24^{\circ} 57^{\prime} 28.0^{\prime \prime} \mathrm{N} ; 106^{\circ} 39^{\prime} 13.2^{\prime \prime} \mathrm{E}\right.$, No.4 in Fig. 1b). The Heshan Fm. consists of the usual bioclastic wackestone-packstone beds (Unit 1). The topmost Permian ash layer (Unit 2$)$ is very thin $(1-2 \mathrm{~cm})$ and overlain by a 20 cm-thick bioclastic limestone (Unit 3). ES1 is an irregular surface that separates Unit 1 from Unit 2, whereas ES2 is a planar surface between Units 2 and 3. ES3 and 4 as exposed in the Wuzhuan and Nanem sections have not been recognized in Youping and are likely amalgamated with ES5 (as arbitrarily chosen here, see Figs. 15 and18). ES3-5 is a gently undulating surface (Fig. 15) that separates the bioclastic limestone (Unit 3) from the overlying microbialites (Unit 6).

The microbial limestone reaches a thickness of $9.2 \mathrm{~m}$ in Youping. The base of the microbialites typically consists of a $20 \mathrm{~cm}$-thick stromatolite bed (Unit 6a). The main part of the microbialites (Unit 6b) comprises clotted thrombolites in its lower part and domes of digitate dendrolites in its upper part (Figs. 3 and 7c-e). The contact between Unit $6 \mathrm{a}$ and $6 \mathrm{~b}$ is a conformable bedding plane without any indication of erosion. Four different textures can be recognized within the clotted thrombolites of this section: layered with 
stromatactis-type fenestral, labyrinthic, vesicular, and spotted. Thrombolites with layered and fenestral textures (Figs. 8c and 9b, c) consists of a sponge-like groundmass of ellipsoidal spheroids (? Renalcis) strewn with highly irregular cavities filled with microcrystalline calcite and dolomite rhombs. Spheroids are usually filled with microcrystalline calcite and cavities resemble stromatactistype fenestral structures with geopetal fillings. These textures associated with diagenetically-altered sponge spicules are also found in the stromatactis-bearing basal Triassic microbial limestone at Shanggan section (Leye area), which represents a local and small tectonic uplift within the Luolou Platform (Baud et al., 2013). These cavities are probably results of decomposition of sponges, cyanobacteria, or algae (Monty, 1976; Flugel, 2004; Vennin et al., 2015). These textures document a close ecological association between sponges and microbialites, as frequently encountered in the latest Permian, newly found in the earliest Triassic (Baud et al., 2013; Friesenbichler et al., 2016) and in later episodes during the Early Triassic (Brayard et al., 2011; Marenco et al., 2012; Vennin et al., 2015; Olivier et al., 2016). Small-sized gastropods, thin-shelled bivalves, and ostracods are abundant in the groundmass, while serpulid worm tubes (assigned to microconchids, Zaton et al., 2013; Yang et al., 2015a, 2015b) are present mostly in the sparite-filled cavities. Ezaki et al. (2008), Lehrmann et al. (2015a) and Baud et al. (2005) described a similar facies in earliest Triassic microbialites from the Nanpanjiang Basin and from western Taurus (SW Turkey). Similar facies were also 
described from later episodes of the Early Triassic, e.g. in the western USA basin (Brayard et al., 2011; Zaton et al., 2013; Vennin et al., 2015; Olivier et al., 2014, 2016). Labyrinthic textures (Figs. 8d, e and 9d) contain abundant, millimetric carbonate crystal fans in a micritic groundmass. Only the micritic part of this texture contains bioclasts (e.g. ostracods and small gastropods). Vesicular mesostructures (Figs. 8f and 9e) contain aligned masses of peloids in a sparitic groundmass showing intense recrystallization and dolomitization. Shelly lenses in the microbialites are essentially composed of bivalves, but also include gastropods and ostracods; coquinoid lenses at the top of the section occasionally contain small-sized ammonoids. A thin exposure gap above the upper limit of the microbial limestone likely corresponds to a weathered volcanogenic greywacke (Unit 7). Above the gap, dark laminated mudstones are interbedded with bioclastic wackestone yielding rare and poorly preserved ammonoids (Unit 8, Fig. 12e).

\subsection{Longyuan}

This section is located south-east of Fengshan $\left(24^{\circ} 25^{\prime} 54.3^{\prime \prime} \mathrm{N}\right.$;

$107^{\circ} 22^{\prime} 24.2^{\prime \prime}$ E, No. 5 in Fig. 1b). The Heshan Fm. is similar to that described in the previous sections. ES1 is also an uneven surface. The topmost Permian ash layer (Unit 2) is $12 \mathrm{~cm}$ thick and is separated from the next overlying bioclastic grainstone (Unit 3 ) by a nearly planar surface (ES2). Unit 3 is only $7 \mathrm{~cm}$ thick 
and contains a shallow marine benthic fauna, with fragmented skeletal grains (Figs. 11d, e, f and 16) and abundant Permian foraminifers (Dagmarita chanakchiensis Reitlinger, 1965; Climacammina sp.; Midiella sp.; Pachyphloia sp.; Geinitzina sp.; Ichthyofrondina sp.; Reichelina sp.; ?Cribrogenerina sp.; ?Sphaerulina sp.; Agathammina pusilla (Geinitz 1848)). Here, ES3 and 4 are not visible and are probably amalgamated with ES5. The microbialites (Unit 6) rests on top of the basal calcarenite bed with a sharp and undulating truncation surface (ES3-5, Figure 11d). Cement and grains of the underlying calcarenite bed (Unit 3) are clearly cut by ES3-5, a surface molded by a $4 \mathrm{~cm}$-thick wavy stromatolite (Unit 6a), as illustrated in Figures $11 \mathrm{e}$ and $\mathrm{f}$. The contact between Unit $6 \mathrm{a}$ and $6 \mathrm{~b}$ is a wavy but conformable surface generated by the inception of domical structures at the top of bed $6 a$.

The total thickness of the microbialites is $7.7 \mathrm{~m}$. This unit exhibits tabular constructions in the lower part of Unit $6 \mathrm{~b}$ and domical constructions in its upper part. Spotted and layered textures with stromatactis-type fenestrae are visible in the clotted thrombolites of the lower part of Unit $6 b$. Three horizons of shelly lenses occur in the domical microbialites. A volcanogenic greywacke (Unit 7) rests directly on top of the microbialites. Above a ca. $1 \mathrm{~m}$-thick exposure gap, dark grey to black, laminated calcareous mudstones of Unit 8 crop out (Fig. 3).

\subsection{Shanmenhai}


The Shanmenhai section is located $14 \mathrm{~km}$ south of Fengshan $\left(24^{\circ} 24^{\prime} 51.90^{\prime \prime} \mathrm{N} ; 107^{\circ} 2^{\prime} 27.50^{\prime \prime} \mathrm{E}\right.$, No. 6 in Fig. $\left.1 \mathrm{~b}\right)$. The Permian part of this section also consists of medium- to thick-bedded $(20-100 \mathrm{~cm})$ limestone of the Heshan Fm., with dark chert nodules and a rich shallow marine benthic fauna. It is overlain by a $12 \mathrm{~m}$-thick microbialite unit at the base of the Luolou Fm. In this section, the detailed transition between the Heshan and the Luolou formations is obscured by small-scale low-angle faults between the two formations. The lower part of the microbialites consists of tabular thrombolites with clotted facies. Vesicular and spotted textures were recognized in the clotted thrombolites. A thinner upper part is characterized by domical structures with a predominant digitate fabric. A $15 \mathrm{~cm}$-thick impure limestone bed containing volcanic material occurs $5 \mathrm{~m}$ above the base of the microbial unit. The microbialite unit is directly capped by a $5 \mathrm{~m}$-thick volcanogenic greywacke (Unit 7), followed by an ammonite- and Claraia sp. indet.-bearing limemudstone, including an intercalated ash layer. Dark laminated mudstones (Unit 8) occur again at the top of this section (Fig. 3).

\subsection{Taiping}

This section is located north of Pingguo $\left(23^{\circ} 29^{\prime} 98.9^{\prime \prime} \mathrm{N} ; 107^{\circ} 31^{\prime} 57.7^{\prime \prime} \mathrm{E}\right.$, No. 7 in Fig. 1b). Here, the Permian Heshan Fm. consists of medium to thick limestone $(20-100 \mathrm{~cm})$ beds containing dark chert nodules intercalated with 
numerous ash layers. It contains a rich shallow-water marine benthic fauna composed of bivalves, gastropods, foraminifers, corals, algae, and echinoderms (Unit 1). It ends with an undulated surface (ES1) capped by a volcanic ash layer (Unit 2). It is overlain by a 40-cm thick bioclastic grainstone (Fig. 12f) rich in Late Permian foraminifers (Nankinella sp.; Dagmarita chanakchiensis Reitlinger 1965; Tubiphytes ex gr. obscurus Maslov, 1956; Frondinodosaria sp.; Pachyphloia sp.; Agathammina pusilla (Geinitz 1848); Pseudovermiporella sp.; Paraglobivalvulina mira Reitlinger, 1965; Midiella sp.) with high-angle cross-bedding (Unit 3) at the base of the Majiaoling Fm. ES3 and 4 are also merged with ES5. A 4.7 m-thick microbial limestone (Unit 6) overlies Unit 3 with a truncation surface (ES3-5, Fig. 17). The calcimicrobial unit is here a basal member common to the Majiaoling and the Luolou formations. Yang et al. (1999) and subsequent authors placed the biostratigraphical Permian-Triassic boundary approximately $1 \mathrm{~m}$ above the base of the microbialite unit on the basis of the FO of $H$. parvus (see also discussion in Yin et al., 2014). Petrographic and facies analyses are documented by Lehrmann et al. (2003, 2015a). The carbon isotope record is given by Krull et al. (2004) and Lehrmann et al. (2015a). The $\delta^{13} \mathrm{C}_{\text {carb }}$ shows a ca. $2 \%$ negative shift at the Heshan-Majiaoling boundary and a steady plateau around $0.5 \%$, which are both consistent with the Wuzhuan and Tienbao records.

New observations also reveal that the microbial limestone is directly overlain by a volcanogenic sandstone, which is at least $5 \mathrm{~m}$ thick (Unit 7). This greywacke 
was interpreted as an ash layer by Lehrmann et al. (2015b). Decimetric lenses of angular clasts of microbial limestone are laterally intercalated within the lowermost meter of the greywacke. These breccias indicate block-faulting activity coeval with deposition of the volcanogenic greywacke and are incompatible with any air-born transportation of the volcanogenic material of the enclosing bed. Inner molds of centimetric bivalves were found in the upper part of the exposed greywacke, below intercalated thin lenses of limestone displaying the typical vermiculate facies generated by intense bioturbation. At Taiping, Lehrmann et al. (2015b) used two volcanoclastic ash layers to linearly extrapolate an age of $251.985 \pm 0.097 \mathrm{Ma}$ for what they interchangeably labelled as the "Permian-Triassic boundary" or "Permian-Triassic event horizon". Lehrmann et al. (2003, 2015a) used the FO of H. parvus for placing the PTB approximately $1 \mathrm{~m}$ above the base of the microbial limestone in Taiping. Yet, Lehrmann et al. (2015b) stated that "the ash layer TP Tuff-3 is ca. $0.5 \mathrm{~m}$ below the PTB at the Taiping section", thus implying that the PTB was newly and correctly moved at the base of the calcarenite and that the reference to the FO of $H$. parvus as a marker for the base of Triassic was abandoned. 


\section{Discussion}

\subsection{Heshan Formation (Units 1 to 2)}

In all investigated sections, the Permian Heshan Fm. is uniform and is characterized by medium- to thick-bedded limestone with wackestonepackstone texture, chert nodules, presence of lime mud, bioclasts of brachiopods, bivalves, bryozoans, crinoids, algae, sponges and foraminifers, and a lack of terrigenous sediments (Unit 1). The high diversity of skeletal grains, the presence of lime mud and the extreme scarcity of hydrodynamic sedimentary structures indicate deposition in a subtidal open-marine platform in low-energy conditions (e.g. Wilson, 1975; Flugel, 2004). However, occasional horizons with a packstone texture suggest sporadic wave and/or storm influences. This part of Heshan Fm. shows no sign of lateral change in bathymetry, except in the Shanggan uplift (3 km north of Leye in the Luolou Platform) where it is replaced by reefal limestone (Baud et al., 2013). According to Yin et al. (2014), the upper Heshan Fm. (our Unit 1) yields the Colaniella-Palaeofusulina biota, including Codonofusulina and Nankinella fusulinids. In our sections, we also identified Colaniella sp., Palaeofusulina sp., Nankinella sp. and other diagnostic Late Permian foraminifers such as Paraglobivalvulina mira and Dagmarita chanakchiensis in the upper Heshan Fm. Despite intensive sampling and processing of a substantial number of large 
samples (4 to $5 \mathrm{~kg}$ each) from the uppermost beds of the Permian Heshan Fm., no age-diagnostic conodont elements were obtained.

In all the sections reported here (Figs. 2, 3), the subtidal Heshan Fm. ends with an ash layer (Unit 2, Fig, 18), whose apatite chemical composition and U$\mathrm{Pb}$ age demonstrate that it originated from the same eruption (Baresel et al., 2015; in press). This ash layer can thus be used as reliable synchronous time line (Fig, 18). This marker is lacking in some sections such as Laren (Galfetti et al., 2008) or Wangmo area (HB unpubl. observations) in the same Luolou Platform. It nevertheless opens up the possibility that it may have acted as a chemically-resistant barrier against dissolution caused by a submarine acidification event that would have removed younger Permian carbonate rocks. The planar bedding plane (ES2 Fig. 18) that separates this ash layer from the basal calcarenite and the absence of reworked Heshan-derived lithoclasts in the calcarenite are in better agreement with chemical dissolution than with mechanical erosion.

In Laolongdong section (Eastern Sichuan), Chongyang section (Southeast Hubei Province) (Yang et al., 2011), and in the Great Bank of Guizhou (e.g. Dajiang, Dawen and Heping sections) (Lehrmann et al., 2003; Chen et al., 2009; Song et al., 2009a; Yin et al., 2014; Lehrmann et al., 2015a), the boundary between the Permian bioclastic limestone and the microbial limestone is a sharp surface, with no equivalents of Units 2 to 5 . This contact is called the "skeletal packstone-calcimicrobial framestone (SP-CF)" boundary by Song et al. (2009a) 
and differs from all our sections by the absence of a terminal ash layer and of foraminiferal-rich grainstones.

\subsection{Onset of the BETM (Units 3 to 5)}

Dating the base of the microbial limestone by means of conodonts is difficult because of i) the generally impoverished conodont record in the lower half of the microbialites (Brosse et al., 2016a); ii) the diachronous FO of $H$. parvus (Baud et al., 1996); and iii) the generally long ranges of conodonts around the PTB (e.g. H. typicalis and H. praeparvus (Jiang et al., 2011)). The FO of $H$. parvus has even been documented immediately below the base of the microbialites at Dajiang section (Jiang et al., 2014), but in most BETM sections, this FO occurs at any depth within the microbialites (e.g. Chen et al., 2009; Mu et al., 2009; Yang et al., 2011). In Wuzhuan, the conodont record is only adequate in the upper part of the microbialites, the lower part being too poor for any robust and reliable dating by means of maximal associations (Brosse et al., 2015). Hence, the $\mathrm{C}$-isotope record temporarily offers a convenient alternative approach for dating the onset of the BETM by means of correlation with conodont-rich PTB sections (e.g. Shangsi and Meishan).

Both $\delta^{13} \mathrm{C}_{\text {carb }}$ records from Tienbao and Wuzhuan show a negative shift of ca. $1 \%$ between the topmost limestone beds (Unit 1) of the Heshan Fm. and the basal calcarenite (Unit 3) of the Luolou Fm. (Figs 2, 3). This shift interrupts the 
protracted negative trend that spans the upper part of the Heshan Fm. and the lower part of the main body of the microbial limestone. Compared to the compressed succession of negative shifts in deeper water sections straddling the PTB (e.g., Xie et al., 2007 for Meishan), this $1 \%$ drop indicates a substantial hiatus within ES1 and/or within ES2.

The most commonly observed succession involyes only a single bioclastic calcarenite (Unit 3 in Taiping, Longyuan, Tienbao and Youping). This basal calcarenite marks the base of the Triassic transgressive sequence above the PTB unconformity. Contradictory interpretations about ES 3 and ES 5 have been proposed either in support of submarine dissolution (e.g. Payne et al., 2007; Song et al., 2009a; Lehrmann et al., 2015a; Lehrmann et al., 2016) or in support of subaerial erosion (e.g. Collin et al., 2009; Wignall et al., 2009; Kershaw et al., 2016). In our sections, any subaerial erosion prior to chemical dissolution cannot be excluded because i): the latter may conceivably erase all traces of the former one as argued by Kershaw et al. (2012b) and ii): both mechanisms do not need to be mutually exclusive. The pendant or meniscus cements are absent in our bioclastic calcarenites and sediments trapped between domical microbialites contain marine fossils. This is in agreement with the absence of traces indicative of subaerial diagenesis as noticed by Lehrmann et al. (2015a). Yet, deposition of a second bioclastic ooid packstone grainstone (Unit 5) characterized by concentration of Late Permian foraminifers (Fig. 5d) indicates a renewed episode of winnowing and reworking. The absence of 
Heshan Fm.-derived lithoclasts within all calcarenites suggests reworking of incompletely lithified Heshan sediments. The upper boundary of the calcarenite is an irregular surface and the transgressive base of the microbialites does not contain any clasts derived from the underlying foraminiferal-rich grainstone. Hence, ES3-5 (Fig. 18) suggests that chemical dissolution took place again shortly before the onset of the microbialites. The interval of uncertainty containing the PTB ranges from ES2 to ES3 in Nanem and Wuzhuan, and from ES2 to ES5 in other sections. Both Nanem and Wuzhuan provide more expanded records of the base of the BETM. There, the oldest bed of microbial limestone (Unit 4) contains Triassic foraminifers and is bracketed by two beds of calcarenite (Units 3 and 5), both of them yielding exclusively Late Permian foraminifers accompanied by ooids. This alternation of shallow water (upper intertidal to supratidal), high-energy calcarenite with subtidal, deeper water microbial limestone suggests that short term eustatic oscillations within a transgressive phase could be a viable mechanism for the succession of Units 3, 4, 5 and 6. An alternative explanation calling upon high frequency tectonic uplift and subsidence appears unlikely. Absence of such alternation of contrasted depositional environments in other sections may result from insufficient accommodation space.

At Nanem and Tienbao, the irregular truncation surface (ES3 or ES5, Fig 18) between the basal calcarenite and oldest microbialites is underlined by a thin crust of iron oxide and bioerosion. These could have formed either in 
subaerial exposures or in submarine hardgrounds. However, the absence of any reworked clasts that would normally be expected along a subaerial erosional surface argues in favor of a submarine dissolution. At Tienbao, burrows cutting through the calcarenite confirm that this unit was lithified or consolidated and thus, provided a suitable substrate for the growth of microbialites. At Longyuan, ES5 is a smoother wavy surface, without bioerosion, root casts, iron oxide, meniscus cement, vadose cement or dissolution residual products that would suggest subaerial exposure.

We suggest that deposition of cross-bedded grainstone and interludes of microbial limestone before the onset of the main microbialite unit are at variance with any long-lasting acidification event of the sea-water. Our observations support brief pulses of acidification only, coeval with some of the described event surfaces. The absence of any intraclasts in the basal calcarenite also lends support to such acidification pulses. The combined global eustatic and local tectonic controls of bathymetry, carbonate supersaturation and local absence of any significant siliciclastic load in shallow waters played a leading role in the onset of the BETM.

Evidence supporting a widespread regression at the PTB in South China is documented in previous studies. In the NE Sichuan Basin, a late Permian dolomitized skeletal grainstone was interpreted as a relative sea-level drop down by Ezaki et al. (2003). North of our study area, Ezaki et al. (2008) also reported a "conglomeratic fusulinid grainstone" in the Longbai section. 
Moreover, Collin et al. (2009) described a thin grainstone bed bounded by two truncation surfaces in the Langbai section that resemble our basal cross-bedded grainstone made of Permian foraminifers (Unit 3, Fig. 12f, 17). Similarly, other sections from South China where bioclastic grainstone is reported include Laolongdong (E Sichuan), Cili (NW Hunan), and Chongyang (SE Hubei) (Yang et al., 2011). Yin et al. (2014) also argued in favor of a widespread regression in South China on the basis of other additional PTB sections in shallow marine settings. Algeo et al. (2007) reported a $12 \mathrm{~cm}$-thick oolitic-pisolitic grainstone at the base of the microbialites from the North Vietnamese part of the Jingxi Platform (Nhi Tao section), which may correlate with the same regressive phase.

Indications of a sea-level fall are also documented in Western Tethys, as reported from Turkey by Marcoux and Baud, (1986) and from the Southern Alps where the rocks at the base of the Tesero oolites were labelled "the current event" by Brandner, (1988) and Brander et al. (2013). Baud et al. (1997, 2005 and 2009a) described the same event in detail from the Çuruk Dag section (Turkey), which is also discussed by Kershaw et al. (2011). In the Demirtas section, Groves et al. (2003, 2005) and Groves and Calner, (2004) labelled this horizon the "disaster oolites". In Turkey, a lens-shaped thrombolite bed is reported at the top of the oolitic calcarenite just below the main microbial stromatolite body by Baud et al. (2009b). More recently, Abdolmaleki and Tavakoli, (2016) also reported a large-ooid facies intercalated within basal 
Early Triassic microbialites in the Persian Gulf Basin. Thus, the alternating oolites and microbialites is a widespread pattern at the Permian-Triassic transition in shallow marine carbonate settings across the Tethys and Panthalassa oceans ( $\mathrm{Li}$ et al., 2015a, 2015b), which strengthens the role of carbonate saturation and eustatic sea-level changes among the parameters that influenced the onset of the microbial limestone. However, by no means does this exclude the intercalation of short acidification events. In the Luolou Platform, the main acidification event may have dissolved the youngest Permian carbonate until the very same underlying ash layer was reached. This ash layer may have reacted with acidic sea water to form a chemical shield against dissolution (Baresel and Widmann, oral com. 2016).

\subsection{Development of the BETM (Units $6 a$ and $b$ )}

In Taiping, Longyuan, Tienbao and Youping, Unit 6a consists of stromatolites whose thickness varies laterally between 2 and $20 \mathrm{~cm}$ (Fig. 13, 15, 16, 17, 18). They are absent from Nanem and Wuzhuan, where tabular clotted microbialites (base of Unit $6 \mathrm{~b}$ ) rests directly on top of the second calcarenite. Tabular clotted microbialites typically occur in the lower part of Unit 6b. In contrast, domical microbialites characterize the upper half of Unit $6 \mathrm{~b}$, where coquinoid lenses of benthic open-marine faunas dominated by bivalves accumulated between the domes (Hautmann et al., 2015). Exquisite preservation 
of these fossils suggests a short transport and quick burial. Micritic fringes of the shells also support the interpretation of carbonate supersaturated waters (Hautmann et al., 2015). The uppermost lenses in Shanggan (Brühwiler et al., 2008) and Youping yielded small-sized specimens of Ophiceras sp. indet. This observation also indicates increasing open marine conditions. A modest deepening within Unit $6 \mathrm{~b}$ at Wuzhuan is also corroborated by the scarcity of anchignathodontid conodonts in the tabular clotted microbialites compared to their diversity and relative abundance within the domical microbialites (Brosse et al., 2015).

The frequent development of domical microbialite in the upper part of the BETM is documented in other sections from South China (e.g. Ezaki et al., 2003, 2008; Yang et al., 2011). However, this change in morphology from tabular to domical thrombolites of South Chinese BETM does not occur in all sections and tabular microbialites may be the persistent macrostructure (Kershaw, 2004). The distribution of these different macrostructures is usually related to bathymetry in equatorial shallow marine settings. However, how tabular versus domical morphologies are controlled by water depth has led to diverging interpretations. On one hand, Ezaki et al. (2003) argued that planar (or tabular) thrombolites grew in low energy, shallow to deep subtidal settings, and domical microbialites grew in intertidal environments. This led Ezaki et al. (2003) to infer a shallowing-upward trend. On the other hand, Kershaw et al. (2011) favored a deepening-upward model on the basis of this change in 
macrostructure. Based on the ecological significance of the observed faunal content as outlined above, our data indicate that the transition from tabular to domical microbialites within Unit $6 \mathrm{~b}$ coincides with deepening.

\subsection{Cessation of the BETM (Units 7 and 8)}

The cessation of the BETM yields highly relevant constraints about what environmental parameters played a role in the deposition of the BETM or not. The transition of the top of the microbial limestone to the next overlying mudstone-wackestone in Tienbao (Fig. 14c, d) and Wuzhuan indicates that the growth of microbial buildups was interrupted by a rapid burial that marks a drowning event throughout the Luolou Platform. Very few sections (e.g. Dajiang and Dawen) lack this drowning event and these typically belong to long-lived horsts (e.g. the GBG). In most sections of the Luolou Platform, the drowning event is also accompanied by deposition of a volcanogenic sandstone (Unit 7). In Tienbao and Wuzhuan sections, the mudstone-wackestone episode does not exceeds one meter in thickness and is overlain by the volcanogenic sandstone marker (Fig. 14c, d). It is abruptly followed by thin- to mediumbedded $(10-30 \mathrm{~cm})$ shaly micritic limestone and dark, laminated, more or less calcareous mudstone (Unit 8). This unit laterally expands to the adjacent troughs where it grades upward from the basal Triassic carbonaceous black shales. Where not weathered, the black mudstone part of Unit 8 resembles the 
basal Griesbachian carbonaceous black shales of the base of the Ziyun Fm. that was deposited in the intervening deeper water downthrown blocks (Fig. 19). In contrast with the Luolou Platform, the boundary between the late Permian deepwater Dalong Fm. and the Early Triassic Ziyun Fm. shows no detectable unconformity. The new Bayesian age model of Baresel et al. (2016) indicates that the Dalong-Ziyun boundary overlaps within errors with the age calibration of the PTB in Meishan GSSP. In the Luolou Fm., volcanogenic sandstones are exceptional and form basin-wide laterally continuous markers such as the Green Bean Rock of late Spathian age (Galfetti et al., 2007; Ovtcharova et al., 2006, 2015). Hence, the volcanogenic sandstone that caps the microbial limestone likely represents a single depositional event considered as a synchronous marker with respect to the cessation of the microbial limestone. The thickness of this volcanogenic greywacke of Griesbachian age varies laterally from a few centimeters up to five meters, suggesting that deposition of remobilized ash layer(s) was largely controlled by local submarine topography. In Wuzhuan, the greywacke occurs between the Griesbachian conodont unitary associations UAZ5 and UAZ6 (Brosse et al., 2015, 2016a). The genesis of such greywackes implies the presence of shallower depositional settings where unconsolidated volcanic ashes can be raised in suspension before settling down again or before being transported as gravity flows at greater depth. Genesis of such greywacke was likely triggered by quakes that release the tectonic stress as encountered in pull-apart basins. In Taiping, the base of the greywacke contains lenses of 
brecciated microbial limestone, thus highlighting the role of block faulting in this drowning event. This marker bed is not reported from persistently uplifted blocks (e.g. Dawen, see Chen et al., 2009 and Dajiang, see Payne et al., 2004).

Thickness of microbial limestone also varies laterally, from less than $4 \mathrm{~m}$ in Tienbao and Taiping (Fig. 3) to ca. $17 \mathrm{~m}$ in Dawen (Chen et al., 2009). Making the simplistic assumption of an approximately constant sedimentation rate for this unit, these lateral variations open up the possibility that cessation of the microbialites within the Nanpanjiang Basin is diachronous. However, all our sections within the Luolou Platform show that the microbial limestone, whatever its thickness, is always capped by the same volcanogenic sandstone as identified by the chemistry of accessory volcanic minerals and $\mathrm{U}-\mathrm{Pb}$ ages (Baresel et al., in press). The presence of this laterally widespread marker bed gives an upper age limit for the cessation of the microbialites and suggests variable sedimentation rates of the microbialites across the different sections. The poor conodont record of Dawen (Chen et al., 2009; see Brosse et al., 2016a) does not allow detecting a diachronous cessation between the GBG and the Luolou Platform. However, correlation of the carbon isotope record between the Luolou Platform and the GBG indicates a diachronous cessation of the microbialites. In Tienbao and Wuzhuan, the $\delta^{13} \mathrm{C}_{\text {carb }}$ values remain stable and close to $0 \%$ across the upper limit of the microbial limestone. Although the precise position of this upper boundary in Dajiang and Dawen is at variance between different authors (compare Payne et al., 2004 with Chen et al., 2009 
and Jiang et al., 2014 ), this boundary is nevertheless associated with a $\delta^{13} \mathrm{C}$ values close to $1 \%$ and within a positive trend unknown from sections outside the GBG. Pending improvements of the conodont record, the carbon isotope record suggests that cessation of the microbial limestone occurred later in the GBG than in the Luolou Platform. Here again, the pattern of this diachronism in time and space was shaped by the submarine paleotopography directly controlled by regional geodynamic constraints. In other words, microbialites thrived longer on shallow-water horsts (e.g. GBG) that escaped blanketing by clastic sediments, while their cessation was concomitant with the earlier drowning and clastic blanketing of the Luolou Platform. Hence, any instantaneous changes in the chemical composition of the water column or in upwelling being turned on or off (Kershaw et al., 2007) are not likely to be among the potential causes that led to the diachronous cessation of the microbial limestone throughout the Nanpanjiang Basin. A further observation compatible with the absence of causal relation with water chemistry is found in the deposition of black shales in intervening troughs (Baresel et al., in revision) that outlasted that of the microbialites on the horsts.

Some authors (e.g. Schubert and Bottjer, 1992; Lehrmann, 1999; Pruss et al., 2006) advocated that microbialites flourished in equatorial shallow waters because of the lack of predation pressure, most grazers having supposedly gone extinct. Main grazer groups in the Early Triassic include echinoids and gastropods. Gastropods do frequently occur and were already diversified within 
the microbialites of the Nanpanjiang Basin (Payne et al., 2006; Kaim et al., 2010; Hautmann et al., 2011, 2015). Hence, the blooming of microbialites cannot be readily assigned to the absence of grazers. Along the same line of thought, the cessation of the BETM did not coincide with any detectable increase in the abundance of grazers.

The cessation of the microbialites does not display a unique pattern within the South China Block. In the Luodian area, its cessation is stepwise rather than abrupt (Ezaki et al., 2008), while it is abrupt and sudden in eastern Sichuan Province (Kershaw et al., 2002; Ezaki et al., 2003). Moreover, there are other sections where the microbialite unit is capped by oolitic limestone, thus suggesting that shallowing was the cause of the cessation. For instance at Yudongzi (Sichuan Province), the microbialite unit is overlain by a regressive oncolitic and oolitic limestone (Kershaw et al., 2012a). In addition, microbialite units in Chongyang (Hubei Province), Cili (Hunan Province), Xiushui (Jiangxi Province) (Yang et al., 2011; Li et al., 2015b) and Hochang (GBG) (Lehrmann et al., 2015a) are also overlain by oolitic limestone (Yang et al., 2011; Li et al., 2015b). In such sections with oolitic limestone, cessation of the microbial limestone cannot be assigned to a change in carbonate supersaturation, but resulted again from a change in bathymetry.

Although microbial limestone of Griesbachian age was deposited during a global sea-level rise that followed the PTB regressive event and its associated hiatus (Kershaw et al., 2012a; Yin et al., 2014), cessation of microbialites was 
largely controlled by regional subsidence or uplift superimposed to a global sealevel rise. Western Tethyan sections show differences in the mode of cessation of microbialites. Stromatolites from Bükk Mountains (Hungary) are gradually diminishing upward. While increasing clastic supply through intensified weathering may equally have contributed to the end of the BETM, a sea-level rise is the most likely explanation for the deposition of overlying calcareous mudstone (Hips and Haas, 2006). In the Çürük Dag section (Turkey), the microbialites are overlain by ca. $25 \mathrm{~m}$ of oolitic grainstone-packstone and followed by Early Triassic shale (Baud et al., 2005, 2009a). Grouped with the underlying microbialites, this carbonate unit has been labelled as "calcimicrobial caprock" by Baud et al. (2005). Here again, reduced bathymetry leading to oolite deposition precedes drowning and deposition of siliciclastics. Kershaw et al. (2011) suggested that local tectonic uplift might have been overridden by the first-order sea-level rise for this succession. In agreement with Kershaw et al. (2012a), the comparison between different sections from South China and from western Tethys suggests that the global sea-level rise during upper Griesbachian times should be the primary controlling factor for the cessation of the BETM, regardless of the variability induced by local tectonics. Time and space distribution of the BETM indicate that bathymetry controlled by regional subsistence or uplift locally modulated the development and cessation of the BETM. 


\subsection{Water chemical composition}

The chemical composition of the water in which the BETM was bathed can be indirectly assessed by the ecological significance of its faunal content. Microbialites are known to be relatively immune to salinity changes (e.g. Dill et al., 1986; Riding, 2000; Kershaw et al., 2011). However, mass abundances of low-diversity assemblages that are a common signature for abnormal salinity (Fürsich, 1993) are unknown from the BETM, thus suggesting normal salinity. The highly diversified benthos recovered from the domical microbialites (Kaim et al., 2010; Hautmann et al., 2011, 2015; Forel et al., 2013) provides a robust argument in support of normal oxygen content and $\mathrm{pH}$. Furthermore, the fine preservation of these benthic faunas also supports the presence of carbonate supersaturated water (Hautmann et al., 2015). The presence of millimetric to centimetric calcite fans (Figs. 12 a, d) in Unit 6 also supports a carbonate supersaturation of the upper part of the water column. In Turkey and Iran (Kershaw et al., 2011; Heydari et al., 2013), basal Triassic microbialites are associated with volumetrically more important calcite fans than in the Nanpanjiang Basin. In addition, carbonate supersaturation is known to favor different types of microbialites (Riding, 2005), as observed in the basal Early Triassic. In conjunction with reduced bathymetry and higher energy, carbonate supersaturation (Groves and Calner, 2004; Calner, 2005; Li et al., 2015a, 2015b; 
Deng et al., 2016) also contributed to the local production of oolites overlying the BETM.

Facies distribution and conodont age constraints of Griesbachian rocks in the Nanpanjiang Basin indicate that anoxic conditions (black shales) straddled the sediment-water interface only in grabens adjacent to the microbialite-bearing horsts. The paleogeographic proximity of carbonaceous $\left(\mathrm{CaCO}_{3}\right.$ yield comprised between 30 and 50\%) and anoxic black shales in the neighboring troughs (Fig. 19) suggests a strong stratification of the water column, somewhat reminiscent of the present-day Black Sea (Kershaw, 2015). It also suggests that carbonate deposition was not restricted to the horsts, but that a modest carbonate flux was exported from the horsts into the grabens. Absence of fine siliciclastics on the microbialite-bearing horsts stands in sharp contrast with their accumulation in lateral anoxic troughs. Wave and storm agitation in the uppermost part of the water column precluded the deposition of siliciclastics on microbialite-bearing horsts and maintained normal oxygen levels in the upper water column. Whether the production of oxygen by microbial photosynthesis alone (Forel et al., 2013) was quantitatively sufficient to sustain the diversified benthos remains an open question. Carbonate supersaturation probably did not cease with the termination of the BETM, as shown by the occasional overlying oolitic and oncolitic grainstone (e.g. Deng et al., 2016) or by the recurrence of later Early Triassic microbialites (Baud et al., 2007; Brayard et al., 2011; Luo et al., 2014b; Saito et al., 2015; Liu et al., 2016). Nor did the isotopic composition 
of the carbonate carbon reservoir undergo any detectable change with the transition from the BETM to the overlying shaly micritic limestone (see Tienbao section, Fig. 3). Payne et al. (2007) hypothesized that the origin of the Early Triassic carbonate saturation could be sought in the dissolved underlying shallow water carbonates of late Permian age. Kershaw et al. (2012a) suggested that the carbonate supersaturation did not undergo drastic changes across the PTB on the basis of the respective amounts of inorganic cement in pre- and post-extinction carbonate. On the whole, any long term change in supersaturation before, during and after the BETM remains elusive. However, brief undersaturation of the ocean is nevertheless needed during any episode of acidification and dissolution of Permian carbonate. A global sea-level rise, the regional tectonic drowning, and the transition to a more humid global climate (Algeo and Twitchett, 2010; Hochuli et al., 2016) may all have contributed to the sharp transition from the BETM to a siliciclastic-dominated sedimentation on the Luolou Platform.

\section{Conclusions}

1- Within the Nanpanjiang pull-apart basin, contrasted paleotopography directly inherited from Late Permian times controlled the spatial distribution of basal Early Triassic sediments, microbialites blooming on horsts and carbonaceous black shales simultaneously accumulating in adjacent troughs. The BETM of 
the Luolou Platform extended over a large uplifted block exceeding $12000 \mathrm{~km}^{2}$ (Luolou Platform) centered on northwestern Guangxi.

2- On the Luolou Platform, the youngest preserved Permian bed is frequently an ash layer whose identity and uniqueness was established by means of apatite chemistry and U-Pb ages (Baresel et al., 2015; in press). This ash layer likely acted as a shield against dissolution caused by any episode(s) of acidification. This maker places a regional lower boundary to the hiatus associated with PTB. 3- The next overlying layer is a bioclastic grainstone essentially composed of winnowed and reworked Late Permian foraminifers, showing evidence of early cementation. This high- energy episode contrasts with the underlying Heshan Fm. and documents a regressive episode. A negative ca.1 \%o jump associated with the bioclastic grainstone is superimposed to the overall decreasing trend in carbonate carbon isotope composition. It indicates a substantial stratigraphic hiatus coincident with the PTB formational change on horsts, as previously detected by conodont Unitary Associations (Brosse et al., 2016a). Any chemical dissolution of the youngest Permian carbonate rocks would equally contribute to this discontinuous pattern of the carbon isotope record.

4- Before deposition of the main microbialite body, up to five Event Surfaces are recognized in sections where accommodation space was available. These surfaces amalgamated where accommodation space was insufficient. These Event Surface place a regional upper boundary to the PTB hiatus. 
5- The contact between the bioclastic grainstone and the overlying microbialites shows different characteristics in the studied sections. At Tienbao and Nanem, the contact is characterized by an undulating irregular relief, the presence of an iron oxide crust, bioerosion, and cuts through Permian grains and groundmass, which can be common features to both subaerial exposures and submarine hardgrounds. However, no direct evidence of subaerial exposure could be detected at the level of microfabrics, but deposition of reworked grainstone containing exclusively Permian foraminifers implies mechanical erosion. The contact at Longyuan is represented by a smooth surface and is lacking any evidence in support of subaerial exposure or submarine hardground. Triassic foraminifers (e.g. Cornuspira $(=$ Postcladella $)$ ) occur within the basal microbial episode, thus excluding any Permian age assignment of the base of the BETM. 6- In Nanem and Wuzhuan, a second bioclastic ooid packstone-grainstone is intercalated between the first microbial bed and the main microbialite body. It also yields reworked Permian bioclasts and foraminifers. These two sections document cycles of deposition of reworked Permian material followed by microbial growth. This alternation indicates that minor bathymetric fluctuations may have controlled the detailed onset of microbialites. Where accommodation was insufficient, these cycles are replaced by an amalgamation surface.

7- In all studied sections, microbialites are generally represented by stromatolites, tabular and domical thrombolites, and dendrolites. Domical microbialites are restricted to the upper part of the BETM. The open marine 
benthic fauna that typically occurs between the domes, as well as the relative abundance of conodonts and the earliest occurrence of ammonoids all indicate that the change from tabular to domical microbialtes was a response to a stepwise increase in bathymetry.

8- An abrupt regional drowning, largely controlled by synsedimentary faulting, is involved in the cessation of microbialites in the Luolou Platform.

Alternatively, smaller scale tectonic uplifts also led to the cessation of the BETM and its capping by oolitic grainstone as documented in the GBG (Lehrmann et al., 2015a). Although the conodont record is not dense enough to demonstrate synchronicity or diachronism of the cessation of the BETM, blanketing by a laterally widely distributed volcanogenic sandstone provides a synchronous marker that may (Shanmenhai, Taiping, Longyuan, Nanem) or may not (e.g. Wuzhuan, Tienbao) directly rest on top of the microbialites. This minor lateral variation suggest that cessation of microbialites was not perfectly synchronous within in the Luolou Platform, as would be expected if their deposition was exclusively controlled by water chemistry at the basin scale. Comparison with other equatorial BETM sections from the northern Yangtze Platform and from outside South China nevertheless suggests that a concomitant global sea-level rise was involved in the cessation of the BETM, as well. The combined effects of regional tectonics and of a global sea-level rise, possibly coupled with increasing weathering rates, shaped the detailed pattern of the cessation of the BETM in time and space. 
9- Biota associated with the BETM in the Nanpanjiang Basin indicates normal oxygenation and salinity. Presence of calcite fans and ooids support carbonate supersaturation of the upper part of the water column where microbialites thrived. Absence of siliciclastics on the microbialite-harboring horsts indicates high energy levels that also insured sufficient oxygenation. Adjacent anoxic troughs indicate very limited or no vertical mixing in the water column. The Early Triassic massive reduction of calcifying metazoans has been listed among the potential causes that would have increase the alkalinity of oceanic waters (Clarkson et al., 2015). Dissolution of Permian carbonates has also been evoked as a possible contribution to supersaturation (Payne et al., 2007). However, carbonate supersaturation did not significantly changed across the PTB as shown by the respective amounts of inorganic cement in pre- and postextinction carbonate (Kershaw et al., 2012a; Baud et al., 2013). Although deep anoxic waters restricted to neighboring grabens may have been an alkaline source, the normal metazoan biota documented from the microbialite-bearing horsts does not support any sustained upwelling of anoxic waters. The occasional deposition of oolitic grainstone capping the BETM also indicates that carbonate supersaturation did equally persist after microbialites ceased blooming. Therefore, a close relation between deposition of microbialites and a coeval change in supersaturation state remains unsubstantiated. Only very short episodes of undersaturation must have accompanied any carbonate dissolution involved into the genesis of the PTB hiatus in shallow water platforms. 
Acknowledgments: Comments on an earlier version of the manuscript by Michael Hautmann and very constructive reviews by Arnaud Brayard, Steve Kershaw, Sylvain Richoz, and editor Ian D. Somerville are deeply acknowledged. Urs Schaltegger is thanked for long term scientific discussions. This research is supported by the Swiss NSF project 200021_135446 (to H.B.) and 200020_156422 (to R.M.). We thank James Neenan for improving the English Text. Jiang Dayong (Peking University) kindly helped with administrative constraints and logistics. 


\section{References:}

Abdolmaleki, J., Tavakoli, V., 2016. Anachronistic facies in the early Triassic successions of the Persian Gulf and its palaeoenvironmental reconstruction. Palaeogeography, Palaeoclimatology, Palaeoecology 446, 213-224.

Adachi, N., Ezaki, Y., Liu, J., 2004. The fabrics and origins of peloids immediately after the end-Permian extinction, Guizhou Province, South China. Sedimentary Geology 164, 161-178.

Algeo, T.J., Ellwood, B., Thoa Nguyen, T.K., Rowe, H., Maynard, J.B., 2007. The Permian-Triassic boundary at Nhi Tao, Vietnam: Evidence for recurrent influx of sulfidic watermasses to a shallow-marine carbonate platform. Palaeogeography, Palaeoclimatology, Palaeoecology 252, 304-327.

Algeo, T.J., Twitchett, R.J., 2010. Anomalous Early Triassic sediment fluxes due to elevated weathering rates and their biological consequences. Geology 38, 1023-1026.

Awramik, S.M., 1990. Stromatolites. In: Briggs, D.E.G., Crowther, P.R., Palaeobiology: a synthesis. Blackwell Scientific Publications, London, 336341.

Baresel, B., Bucher, H., Brosse, M., Bagerphour, B., Schaltegger, U., 2015. Ultra-high precision dating of mass extinction events: a combined zircon geochronology, apatite tephrochronology, and Bayesian age modelling approach of the Permian-Triassic boundary extinction. 13th Swiss Geoscience Meeting, Basel. 
Baresel, B., Bucher, H., Brosse, M., Cordey, F., Guodun, K., Schaltegger, U., in review, 2016. Precise age for the Permian-Triassic boundary in South China from high precision $\mathrm{U}-\mathrm{Pb}$ geochronology and Bayesian age-depth modelling. Solid Earth. DOI:10.5194/se-2016-145

Baresel, B., Bucher, H., Bagherpour, H., Brosse, M., Guodun, K., Schaltegger, U., From icehouse to hothouse: Timing of the global regression marking the Permian-Triassic boundary crisis and of the following microbial bloom. Scientific Reports (In revision)

Baresel, B., d'Abzac, F.X., Bucher, H., Schaltegger, U., in press. High-precision time-space correlation through coupled apatite and zircon tephrochronology: an example from the Permian-Triassic boundary in South China. Geology. DOI: $10.1130 / \mathrm{G} 38181.1$

Bartley, J.K., Knoll, A.H., Grotzinger, J.P., Sergeev, V.N., 2000. Lithification and fabric genesis in precipitated stromatolites and associated peritidal carbonates, Mesoproterozoic Billyakh Group, Siberia. In: J.P. Grotzinger, N.P. James (Eds.), Precambrian Carbonates, 65, Society of Economic Paleontologists and Mineralogists Special Publication, Tulsa, Oklahoma, 59-74.

Baud, A., 1996. The Permian-Triassic boundary: recent developments, discussion and proposals. Albertina 18, 6-9.

Baud, A., Cirilli, S., Marcoux, J., 1997. Biotic response to mass extinction: the Lowermost Triassic microbialites. Facies 36, 238-242. 
Baud, A., Richoz, S., Cirilli, S., Marcoux, J., 2002. Basal Triassic carbonate of the Tethys: a microbialite world. 16th International Sedimentological Congress, Johannesburg, Abstract Volume, 24-25.

Baud, A., Richoz, S., Marcoux, J., 2005. Calcimicrobial cap rocks from the basal Triassic units: western Taurus occurrences (SW Turkey). Comptes Rendus Palevol 4, 569-582.

Baud, A., Richoz, S., Pruss, S., 2007. The Lower Triassic anachronisitic carbonate facies in space and time. Global and Planetary Change 55, 81-89.

Baud, A., Crasquin, S., Forel, M.B., Richoz, S., 2009a. The Permian-Triassic transition at the Çürük dag section (South Turkey). In: Craquin et al., (Eds.) IGCP 572 Field Guide Book: The Permian-Triassic transition in the Southwestern Taurus Mountains (South Turkey), Antalya, 19-28.

Baud, A., Richoz, S., 2009b. The Permian-Triassic transition at the Demirtas section. In: Crasquin et al., (Eds.) IGCP 572 Field Guide Book: The PermianTriassic transition in the Southwestern Taurus Mountains (South Turkey), Volume Field Guide Book 1: Antalya, 29-35.

Baud, A., Bucher, H., Brosse, M., Frisk, A., Guodun, K., 2013. Stromatactis limestone below and above the Permian-Triassic boundary event: evidence of sponge microbial build-up. In: Zhong-Qiang, C., Hao, Y., Genming, L. (Eds.), World summit on P-Tr mass extinction \& extreme climate change. State Key Laboratory of Biogeology and Environmental Geology, China University of Geosciences, Wuhan, China 8-9. 
Baud, A., Goudemand, N., Brosse, M., Frisk, Å.M., Bucher, H., Richoz, S., 2014. Oman oases: contrasting carbonates sediments on the Gondwana margin in the immediate aftermath of the Permian-Triassic boundary mass extinction. In 19th International Sedimentological Congress 2014, Geneva, Switzerland, Abstract book, 54 .

Brandner, R., 1988. The Permian-Triassic Boundary in the Dolomite (Southern Alp, Italy), San Antonio Section. Berichte der Geologichen Bundesanstalt 15, 49-56.

Brandner, R., Horacek, M., Keim, L., 2013. Permian-Triassic-Boundary and Lower Triassic in the Dolomites, Southern Alps (Italy), Field Trip Guide. Journal of Alpine Geology 54, 379-404.

Brayard, A., Vennin, E., Olivier, N., Bylund, K.G., Jenks, J., Stephen, D.A., Bucher, H., Hofmann, R., Goudemand, N., Escarguel, G., 2011. Transient metazoan reefs in the aftermath of the end-Permian mass extinction. Nature Geoscience 4, 693-697.

Brosse, M., Bucher, H., Bagherpour, B., Baud, A., Frisk, Å., Guodun, A., Goudemand, N., 2015. Conodonts from the Early Triassic microbialite of Guangxi (South China): implications for the definition of the base of the Triassic System. Palaeontology 58 (3), 563-584.

Brosse, M., Bucher, H., Goudemand, N., 2016a. Quantitative biochronology of the Permian-Triassic boundary in South China based on conodont unitary associations. Earth-Science Reviews 155, 153-171. 
Brosse, M., Baud, A., Bucher, H., Goudemand, N., Nützel, A., Ware, D., Frisk, A., Hagdorn, H., 2016b. Basal Triassic exotic blocks from Oman: the promised land, no raft of the medusa. 14th Swiss Geoscience Meeting, Geneva.

Brosse, M., Bucher, H., Goudemand, N., 2016c. Reply to the Comment on "Quantitative biochronology of the Permian-Triassic boundary in South China based on conodont unitary associations". Earth Science Reviews. DOI: 10.1016/j.earscirev.2016.07.015.

Brühwiler, T., Brayard, A., Bucher, H., Guodun, K., 2008. Griesbachian and Dienerian (Early Triassic) ammonoid faunas from northwestern Guangxi and southern Guizhou (south China). Palaeontology 51 (5), 1151-1180.

Burgess, S.D., Bowring, S., Shen, S.Z., 2014. High-precision timeline for Earth's most severe extinction. Proceedings of the National Academy of Sciences 111, 3316-3321.

Calner, M., 2005. A Late Silurian extinction event and anachronistic period. Geology 33, 305-308.

Chen, J., Beatty, T.W., Henderson, C.M., Rowe, H., 2009. Conodont biostratigraphy across the Permian-Triassic boundary at the Dawen section, Great Bank of Guizhou, Guizhou Province, South China: implications for the late Permian extinction and correlation with Meishan. Journal of Asian Earth Sciences 36 (2), 442-458.

Chivas, A.R., Torgersen, T., Polach, H.A., 1990. Growth rates and Holocene development of stromatolites from Shark Bay, Western Australia. Australian Journal of Earth Sciences 37, 113-121. 
Clarkson, M.O., Kasemann, S.A., Wood, R.A., Lenton, T.M., Daines, S.J., Richoz, S., Ohnemueller, F., Meixner, A., Poulton, S.W., Tipper, E.T., 2015. Ocean acidification and the Permo-Triassic mass extinction. Science 348 (6231), 229-232.

Collin, P.Y., Kershaw, S., Crasquin, S., Feng, Q., 2009. Facies changes and diagenetic processes across the Permian-Triassic boundary event horizon, Great Bank of Guizhou, South China: a controversy of erosion and dissolution. Sedimentology 56, 677-693.

Deng, B., Wang, Y., Woods, A., Li, S., Li, G., Chen, W., 2016. Evidence for rapid precipitation of calcium carbonate in South China at the beginning of Early Triassic. Palaeogeography, Palaeoclimatology, Palaeoecology in Press. http://dx.doi.org/10.1016/j.palaeo.2016.06.007

Dill, R.F., Shinn, E.A., Jones, A.T., Kelly, K., Steinen, R.P., 1986. Giant subtidal stromatolites forming in normal salinity waters. Nature $324,55-58$.

Dunham, R.J., 1962. Classification of carbonate rocks according to depositional texture. American Association of Petroleum Geologists memoir 1, 108-121.

Ezaki, Y., Liu, J., Adachi, N., 2003. Earliest Triassic microbialite micro to megastructures in the Huaying area of Sichuan Province, south China: implications for the nature of oceanic conditions after the end-Permian extinction. Palaios 18, 388-402.

Ezaki, Y., Liu, J., Nagano, T., Adachi, N., 2008. Geobiological aspects of the earliest Triassic microbialites along the southern periphery of the tropical 
Yangtze Platform: initiation and cessation of a microbial regime. Palaios 23, $356-369$.

Fan, G., Wang, Y., Kershaw, S., Li, G., Meng, Z., Lin Q., Yuan Z., 2014. Recurrent breakdown of Late Permian reef communities in response to episodic volcanic activities: evidence from southern Guizhou in South China. Facies 60, 603-613.

Faure, M., Lin, W., Chu, Y., Lepvrier, C., 2016. Triassic tectonics of the southern margin of the South China Block. Comptes Rendus Geoscience 348, $5-14$.

Feng, Z.Z., Bao, Z.D., Zheng, X.J., Wang, Y., 2015. There was no "Great Bank of Guizhou" in the Early Triassic in Guizhou Province, South China. Journal of Palaeogeography 4 (1), 99-108.

Flugel, E., 2004. Microfacies of carbonate rocks. Springer.

Forel, M.B., Crasquin, S., Kershaw, S., Collin, P.Y., 2013. In the aftermath of the end-Permian extinction: the microbialite refuge? Terra Nova 25, 137-143.

Friesenbichler, E., Baud, A., Krystyn, L., Sahakyan, L., Richoz, S., 2016. Basal Induan (Early Triassic) giant sponge-microbial build-ups in Armenia: microfacies analyses and carbon isotope studies. GSA Annual Meeting in Denver, Colorado, USA. Paper No. 225-11.

Fürsich, F.T., 1993. Palaeoecology and evolution of Mesozoic salinitycontrolled benthic macroinvertebrate associations. Lethaia, 26 (4), 327-346. 
Galfetti, T., Bucher, H., Ovtcharova, M., Schaltegger, U., Brayard. A., Brühwiler, T., Goudemand, N., Weissert, H., Hochuli, P.A., Cordey, F., Goudun, K., 2007. Timing of the Early Triassic carbon cycle perturbations inferred from new $\mathrm{U}-\mathrm{Pb}$ ages and ammonoid biochronozones. Earth and Planetary Science Letters 258, 593-604.

Galfetti, T., Bucher, H., Martini, R., Hochuli, P.A., Weissert, H., Crasquin, S.S., Brayard, A., Goudemand, N., Brühwiler, T., Guodun, K., 2008. Evolution of Early Triassic outer platform paleoenvironments in the Nanpanjiang Basin (South China) and their significance for the biotic recovery. Sedimentary Geology 204, 36-60.

Groves, J.R., Altiner, D., Boyce, M., Craig, B.J., 2003. ' Disaster oolites”' in the Permian-Triassic boundary interval, Tauride Mountains (Turkey). Geological Society of America, North-Central Section Meeting, Abstracts with programs, 35 (2), 48.

Groves, J.R., Calner, M., 2004. Lower Triassic oolites in Tethys: a sedimentologic response to the end-Permian mass extinction. Geological Society of America Abstracts with programs 36 (5), 336.

Groves, J.R., Altiner, D., Rettori, R., 2005. Decline and recovery of lagenide foraminifers in the Permian-Triassic boundary interval (Central Taurides, Turkey). Paleontological Society Memoir 62 [supplement to Journal of Paleontology, 79(4)], 38 p.

Halpin, J.A., Tran, H.T., Lai, C.K., Meffre, S., Crawford, A.J., Zaw, K., 2016. $\mathrm{U}-\mathrm{Pb}$ zircon geochronology and geochemistry from NE Vietnam: A 
'tectonically disputed' territory between the Indochina and South China blocks. Gondwana Research 34, 254-273.

Hautmann, M., Bucher, H., Brühwiler, T., Goudemand, N., Kaim, A., Nützel, A., 2011. An unusually diverse mollusc fauna from the earliest Triassic of South China and its implications for benthic recovery after the end-Permian biotic crisis. Geobios 44 (1), 71-85.

Hautmann, M., Bagherpour, B., Brosse, M., Frisk, A., Hofmann, R., Baud, A., Nützel, A., Goudemand, N., Bucher, H., 2015. Competition in slow motion: The unusual case of benthic marine communities in the wake of end-Permian mass extinction. Palaeontology 58 (5), 871-901.

Hermann, E., Hochuli, P.A., Méhay, S., Bucher, H., Brühwiler, T., Hautmann, M., Ware, D., Roohi, G., Rehman, K., Yaseen, A., 2011. Organic matter and palaeoenvironmental signals in the Early Triassic of the Salt Range and Surghar Range. Sedimentary Geology 234, 19-41.

Heydari, E., Arzani, N., Safaei, M., Hassanzadeh, J., 2013. Ocean's response to a changing climate: Clues from variations in carbonate mineralogy across the Permian-Triassic boundary of the Shareza Section, Iran. Global and Planetary Change 105, 79-90.

Hips, K., Haas, J., 2006. Calcimicrobial stromatolites at the Permian-Triassic boundary in a western Tethyan section, Bükk Mountains, Hungary. Sedimentary Geology 185, 239-253.

Hochuli, P.A., Sanson-Barrera, A., Schneebeli-Hermann, E., Bucher, H., 2016. Severest crisis overlooked-Worst disruption of terrestrial environments 
postdates the Permian-Triassic mass extinction. Nature Scientific Reports 6:28372.

Jiang, H., Aldridge, R.J., Lai, X., Yan, C., Sun, Y., 2011. Phylogeny of the conodont genera

Hindeodus and Isarcicella across the Permian-Triassic boundary. Lethaia 44 (4),

374-382.

Jiang, H., Lai, X., Sun, Y., Wignall, P.B., Liu, J., Yan, C., 2014. PermianTriassic conodonts from Dajiang (Guizhou, South China) and their implication for the age of microbialite deposition in the aftermath of the End-Permian mass extinction. Journal of Earth Science 25 (3), 413-430.

Kaim, A., Nützel, A., Bucher, H., Brühwiler, T., Goudemand, N., 2010. Early Triassic (Late Griesbachian) gastropods from South China (Shanggan, Guangxi). Swiss Journal of Geosciences 103 (1), 121-128.

Kershaw, S., Zhang, T., Lan, G., 1999. A ?microbialite crust at the PermianTriassic boundary in south China, and its palaeoenvironmental significance. Palaeogeography, Palaeoclimatology, Palaeoecology 146, 1-18.

Kershaw, S., Guo, L., Swift A., Fan, J., 2002. ?Microbialites in the PermianTriassic boundary interval in central China: structure, age and distribution. Facies 47, 83-90.

Kershaw. S., 2004. Comment-Earliest Triassic microbialite micro- to megastructures in the Huaying area of Sichuan Province, south China: 
implications for the nature of oceanic conditions after the end-Permian extinction (Ezaki et al., 2003). Palaios 19, 414-416.

Kershaw, S., Li, Y., Crasquin, S.S., Feng, Q., Mu, X., Collin, P.Y., Reynolds, A., Guo, L., 2007. Earliest Triassic microbialites in the South China block and other areas: controls on their growth and distribution. Facies 53, 409-425.

Kershaw, S., Crasquin, S., Forel, M.B., Randon, C., Collin, P.Y., Kosun, E., Richoz, S., Baud, A., 2011. Earliest Triassic microbialites in Cürük Dag, southern Turkey; composition, sequences and controls on formation. Sedimentology 58, 739-755.

Kershaw, S., Crasquin, S., Li, Y., Collin, P.Y., Forel, M. B., Mu, X., Baud, A., Wang, Y., Xie, S., Mauer, F., Guo, L., 2012a. Microbialites and global environmental change across the Permian-Triassic boundary: a synthesis. Geobiology 10, 25-47.

Kershaw, S., Crasquin, S.D., Li, Y., Collin, P.Y., Forel, M.B., 2012b. Ocean acidification and the end-Permian mass extinction: to what extent does evidence support hypothesis? Geosciences 2, 221-234.

Kershaw, S., 2015. Modern Black Sea oceanography applied to the end-Permian extinction event. Journal of Palaeogeography 4 (1), 52-62

Kershaw, S., Collin, P.Y., Crasquin, S., 2016. Comment to Lehrmann et al. New sections and observations from the Nanpanjiang Basin, South China. Palaios, 31, 111-117. 
Kozur, H., 2005. Pelagic uppermost Permian and the Permian-Triassic boundary conodonts of Iran. Part II: Investigated sections and evaluation of the conodont faunas. Hallesches Jahrbuch Geowissenschaften Reihe B 19, 49-86.

Kozur, H.W., 2007. Biostratigraphy and event stratigraphy in Iran around the Permian Triassic Boundary (PTB): implications for the causes of the PTB biotic crisis. Global and Planetary Change 55 (1-3), 155-176.

Krull, E.S., Lehrmann, D.J., Druke, D., Kessel, B., Yu, Y., Li, R., 2004. Stable carbon isotope stratigraphy across the Permian-Triassic boundary in shallow marine carbonate platforms, Nanpanjiang Basin, South China. Palaeogeography, Palaeoclimatology, Palaeoecology 204, 297-315.

Krystyn, L., Richoz, S., Baud, A., Twitchett, R.J., 2003. A unique PermianTriassic boundary section from the Neotethyan Hawasina Basin, Central Oman Mountains. Palaeogeography, Palaeoclimatology, Palaeoecology 191, 329-344.

Leda, L., Korn, D., Ghaderi, A., Hairapetian, V., Struck, U., Reimold,W.U., 2014. Lithostratigraphy and carbonate microfacies across the Permian-Triassic boundary near Julfa

(NW Iran) and in the Baghuk Mountains (Central Iran). Facies 60 (1), 295-325. Lehrmann, D.J., Jiayong, W., Enos, P., 1998. Controls on facies architecture of a large Triassic carbonate platform: The Great Bank of Guizhou, Nanpanjiang Basin South

China. Journal of Sedimentary Research 68 (2), 311-326.

Lehrmann, D.J., 1999. Early Triassic calcimicrobial mounds and biostromes of the Nanpanjiang Basin, South China. Geology 27, 359-362. 
Lehrmann, D.J., Payne, J.L., Felix, S.V., Dillett, P.M., Wang, H., Yu, Y.Y., Wei, J.Y., 2003. Permian-Triassic boundary sections from shallow marine carbonate platforms of the Nanpanjiang Basin, South China: implications for oceanic conditions associated with the end-Permian extinction and its aftermath. Palaios 18, 138-152.

Lehrmann, D.J., Donghong, P., Enos, P., Minzoni, M., Ellwood, B.B., Orchard, M.J., Jiyan, Z., Jiayong, W., Dillett, P., Koenig, J., Steffen, K., Druke, D., Druke, J., Kessel, B., Newkirk, T., 2007a. Impact of differential tectonic subsidence on isolated carbonate platform evolution: Triassic of the Nanpanjiang basin, south China. American Association Petroleum Geologists Bulletin 91 (3), 287-320.

Lehrmann, D.J., Payne, J.L., Pei, D., Enos, P., Druke, D., Steffen, K., Zhang, J., Wei, J., Orchard, M.J., Ellwood, B., 2007b. Record of the end-Permian extinction and Triassic biotic recovery in the Chongzuo-Pinnguo platform, southern Nanpanjiang Basin, Guangxi, South China. Palaeogeography, Palaeoclimatology, Palaeoecology 252, 200-217.

Lehrmann, D.J., Bentz, J.M., Wood, T., Goers, A., Dhillon, R., Akin, S., Li, X., Payne, J.L., Kelley, B.M., Meyer, K.M., Schaal, E.K., Suarez, M.B., Yu, M., Qin, Y., Li, R., Minzoni, M., Henderson, C.M., 2015a. Environmental controls on the genesis of marine microbialites and dissolution surface associated with the end-Permian mass extinction: new Sections and observations from the Nanpanjiang basin, South China. Palaios 30, 529-552.

Lehrmann, D.J., Stepchinski, L., Altiner, D., Orchard, M.J., Montgomery, P., Enos, P., Ellwood, B.B., Bowring, S.A., Ramezani, J., Wangh, H., Wei, J., Yu, M., Griffiths, J.D., Minzoni, M., Schaal, E.K., Li, X., Meyer, K.M., Payne, J.L., 
2015b. An integrated biostratigraphy (conodonts and foraminifers) and chronostratigraphy (paleomagnetic reversals, magnetic susceptibility, elemental chemistry, carbon isotopes and geochronology) for the Permian-Upper Triassic strata of Guandao section, Nanpanjiang Basin, south China. Journal of Asian Earth Sciences 108, 117-135.

Lehrmann, D.J., Bentz, J.M., Wood, T., Goers, A., Dhillon, R., Akin, S., Li, X., Payne, J.L., Kelley, B.M., Meyer, K.M., Schaal, E.K., Suarez, M.B., Yu, M., Qin, Y., Li, R., Minzoni, M., Henderson. C.M., 2016. Reply: Permian-Triassic microbialite and dissolution surface environmental controls on the genesis of marine microbialites and dissolution surface associated with the end-Permian mass extinction: new sections and observations from the Nanpanjiang Basin, South China. Palaios 31, 118-121.

Li, X.,Yu, M., Lehrmann, D.J., Payne, J.L., Kelley, B.M., Minzoni, M., 2012. Factors controlling carbonate platform asymmetry: Preliminary results from the Great Bank of Guizhou, an isolated Permian-Triassic Platform in the Nanpanjiang Basin, south China. Palaeogeography, Palaeoclimatology, Palaeoecology, 315-316, 158-171.

Li, T., Bottjer, D., Tong, J., Li, F., Yang, T., Song, H., Song, H., Liang, L., 2015a. Distribution and size variation of ooids in the aftermath of the PermianTriassic mass extinction. Palaios 30 (9), 714-727.

Li, F., Yan, J., Chen, Z.Q., Ogg, J.G., Tian, L., Korngreen, D., Liu, K., Ma, Z., Woods, A. D., 2015b. Global oolite deposits across the Permian-Triassic boundary: a synthesis and implications for palaeoceanography immediately after the end-Permian biocrisis. Earth-Science Reviews 149, 163-180. 
Liu, J.B., Ezaki, Y., Yang, S.R., Wang, H.F., Adachi, N., 2007. Age and sedimentology of microbialites after the end-Permian mass extinction in Luodian, Guizhou Province. Journal of Palaeogeography 9, 473-486. (In Chinese)

Liu, S., Wang, J., Yin, F., Xie, T., Hu, S., Guan, X., Zhang, Q., Zhou, C., Cheng, W., Xu, J., 2016. Early Triassic stromatolites from the Xingyi area, Guizhou Province, southwest China: geobiological features and environmental implications. Carbonates Evaporites. DOI:10.1007/s13146-016-0318-1

Luo, G., Algeo, T.J., Huang, J., Zhou, W., Wang, Y., Yang, H., Richoz, S., Xie, S., 2014a. Vertical $\delta 13$ Corg gradients record changes in planktonic microbial community composition during the end-Permian mass extinction, Palaeogeography, Palaeoclimatology, Palaeoecology 396, 119-131.

Luo, M., Chen, Z.Q., Zhao, L., Kershaw, S., Huang, J., Wu, L., Yang, H., Fang, Y., Huang, Y., Zhang, Q., Hu, S., Zhou, C.,Wen, W., Jia, Z., 2014b. Early Middle Triassic stromatolites from the Luoping area, Yunnan Province, Southwest China: Geobiologic features and environmental implications. Palaeogeography, Palaeoclimatology, Palaeoecology 412, 124-140.

Marcoux, J., Baud, A., 1986. The Permo-Triassic boundary in the Antalya Nappes (western Taurides, Turkey). Memorie della Societa Geologica Italiana 34, 243-252.

Marenco, P.J., Griffin, J.M., Fraiser, M.L., Clapham, M.E., 2012. Paleoecology and geochemistry of Early Triassic (Spathian) microbial mounds and 
implications for anoxia following the end- Permian mass extinction. Geology 40 (8), 715-718.

Monty, C., 1976. The origin and development of cryptalgal fabrics. In:

Stromatolites (Ed. M.R. Walker). Developments in Sedimentology 20, 193-250.

Mu, X., Kershaw, S., Li Yue., Guo, L., Qi, Y., Reynolds, A., 2009. Highresolution carbon isotope changes in the Permian-Triassic boundary interval, Chongqing, South China; implications for control and growth of earliest Triassic microbialites. Journal of Asian Earth Sciences 36 (6), 434-441.

Olivier, N., Brayard, A., Fara, E., Bylund, K.G., Jenks, J. F., Vennin, E., Stephen, D.A., Escarguel, G., 2014. Smithian Shoreline migrations and depositional settings in Timpoweap Canyon (Early Triassic, Utah, USA). Geological Magazine 151,938-955.

Olivier, N., Brayard, A., Vennin, E., Escarguel, G., Fara, E., Bylund, K.G., Jenks, J.F., Caravaca, G., Stephen, D.A., 2016. Evolution of depositional settings in the Torrey area during the Smithian (Early Triassic, Utah, USA) and their significance for the biotic recovery. Geological Journal 51, 600-626.

Ovtcharova, M., Bucher, H., Schaltegger, U., Galfetti, T., Brayard, A., Guex, J., 2006. New early to middle Triassic U-Pb ages from South China: Calibration with the ammonoid biochronozones and implications for the timing of the Triassic biotic recovery. Earth and Planetary Science Letters 243, 463-475.

Ovtcharova, M., Goudemand, N., Hammer, Ø., Goudun, K., Cordey, F., Galfetti, T., Schalttegger, U., Bucher, H., 2015. Developing a strategy for accurate definition of a geological boundary through radio-isotopic and 
biochronological dating: The Early-Middle Triassic boundary (South China). Earth-Science Reviews 146, 65-76.

Payne, J.L., Lehrmann, D.J., Wei, J., Orchard, M.J., Schrag, D.P., Knoll, A.H., 2004. Large perturbations of the carbon cycle during recovery from the endPermian extinction. Science 305 (5683), 506-509.

Payne, J.L., Lehrmann, D.J., Wei, J., Knoll, A.H., 2006. The Pattern and Timing of Biotic Recovery from the End- Permian Extinction on the Great Bank of Guizhou, Guizhou Province, China. Palaios 21, 63-85.

Payne, J.L., Lehrmann, D.J., Follett, D., Seibel, M., Kump, L.R., Riccardi, A., Altiner, D., Sano, H., Wei, J., 2007. Erosional truncation of uppermost Permian shallow-marine carbonates and implications for Permian-Triassic boundary events. Geological Society of America Bulletin 119, 771-784.

Pruss, S.B., Bottjer, D.J., Corsetti, F.A., Baud, A., 2006. A global marine sedimentary response to the end-Permian mass extinction: examples from southern Turkey and the western United States. Earth science reviews 78, 193206.

Raup, D.M., 1979. Size of the Permo-Triassic bottleneck and its evolutionary implications. Science 206, 217-218.

Richoz, S., Krystyn, L., Baud, A., Brandner, R., Horacek, M., Mohtat-Aghai, P., 2010. Permian Triassic boundary interval in the Middle East (Iran and N. Oman): progressive environmental change from detailed carbonate carbon 
isotope marine curve and sedimentary evolution. Journal of Asian Earth Sciences 39, 236-253.

Ricou, L.E., 1994. Tethys reconstructed: plates, continental fragments and their boundaries since $260 \mathrm{Ma}$ from central America to south-eastern Asia. Geodynamica Acta 7 (4), 169-218.

Riding, R., 2000. Microbial carbonates: the geological record of calcified bacterial-algal mats and biofilms. Sedimentology 47, 179-214.

Riding. R., 2005. Phanerozoic reefal microbial carbonate abundance: comparisons with metazoan diversity, mass extinction events, and seawater saturation state. Revista Espanola de Micropaleontologia 37, 23-39.

Riding, R., 2011. Reefalmicrobial crusts. In: Encyclopedia of Modern Coral Reefs (ed. Hopley D). Encyclopedia of Earth Science Series, Springer, Heidelberg 911-915.

Saito, R., Kaiho, K., Oba, M., Fujibayashi, M., Tong, J., Tian, L., 2015. Predominance of archaea-derived hydrocarbons in an Early Triassic Microbialite. Organic Geochemistry 85, 66-75

Sanson-Barrera, A., Hochuli, P.A., Bucher, H., Schneebeli-Hermann, E., Meier, M., Weissert, H., Bernasconi, S., 2015. Late Permian-earliest Triassic high resolution organic carbon isotope and palynofacies records from Kap Stosch (northeast Greenland). Global and Planetary Changes 133, 149-166.

Schneebeli-Hermann, E., Kürschner, W.M., Hochuli, P.A., Ware, D., Weissert, H., Bernasconi, S.M., Roohi, G., Rehman, K., Bucher, H., 2013. Evidence for 
atmospheric carbon injection during end-Permian extinction. Geology 41 (5), 579-582.

Schubert, J.K., Bottjer, D.J., 1992. Early Triassic stromatolites as post-mass extinction disaster forms. Geology 20, 883-886.

Sepkoski, J.J.Jr., 1984. A kinetic-model of Phanerozoic taxonomic diversity 3. Post-Paleozoic families and mass extinctions. Paleobiology 10, 246-267.

Sepkoski, J.J.Jr., Bambach. R.K., Droser, M.L., 1991. Secular changes in Phanerozoic event bedding and the biological overprint. In: Cycles and Events in Stratigraphy (eds Einsele G, Ricken W, Seilacher A). Berlin, Springer 298312.

Shapiro, R.S., 2000. A comment on the systematic confusion of thrombolites. Palaios 15, 166-169.

Song, H.J., Tong, J.N., Chen, Z.Q., Yang, H., Wang, Y.B., 2009a. End-Permian mass extinction of foraminifers in the Nanpanjiang Basin, South China. Journal of Paleontology 83, 718-738.

Song, H., Tong, J., Chen, Z.Q., 2009b. Two episodes of foraminiferal extinction near the Permian-Triassic boundary at the Meishan section, South China. Australian Journal of Earth Sciences 56 (6), 765-773.

Song, H., Yang, L., Tong, J., Chen, J., Tian, L., Song, H., Chu, D., 2015. Recovery dynamics of foraminifers and algae following the Permian-Triassic extinction in Qingyan, South China. Geobios 48 (1), 71-83. 
Spötl C., Vennemann T.W., 2003. Continuous-flow IRMS analysis of carbonate minerals. Rapid Communications in Mass Spectrometry 17, 1004-1006.

Taraz, H., Golshani, F., Nakazawa, K., Shimizu, D., Bando, Y., Ishii, K-I., Murata, M., Okimura, Y., Sakagami, S., Nakamura, K., Tukuoka, T., 1981. The Permian and the Lower Triassic systems in Abadeh region, central Iran. Mem Fac Sci Kyoto Univ Ser Geol Miner 47, 62-133.

Thanh, N.X., Hai, T.T., Hoang, N., Lan, V.Q., Kwon, S., Itaya, T., Santosh, M., 2014. Backarc mafic-ultramafic magmatism in Northeastern Vietnam and its regional tectonic significance. Journal of Asian Earth Sciences 90, 45-60.

Vennin, E., Olivier, N., Brayard, A., Bour, I., Thomazo, C., Escarguel, G., Fara, E., Bylund, K.G., Jenks, J.F., Stephen, D.A., Hofmann, R., Pufahl, P., 2015. Microbial deposits in the aftermath of the end-Permian mass extinction; a diverging case from the Mineral Mountains (Utah, USA). Sedimentology 62(3), 753-792.

Wignall, P.B., Hallam, A., 1993. Griesbachian (Earliest Triassic) palaeoenvironmental changes in the Salt Range, Pakistan and southeast China and their bearing on the

Permo-Triassic mass extinction. Palaeogeography, Palaeoclimatology, Palaeoecology $102,215-237$.

Wignall, P.B., Kershaw, S., Collin, P.Y., Crasquin, S.S., 2009. Erosional truncation of uppermost Permian shallow-marine carbonates and implications 
for Permian-Triassic boundary events: Comment. Geological Society of America Bulletin 121 (5-6), 954-956.

Wilson, J.L., 1975. Carbonate facies in geological history. Springer.

Xie, S.C., Pancost, R.D., Huang, J.H., Wignall, P.B., Yu, J.X., Tang, X.Y., Chen, L., Huang, X.Y., Lai, X.L., 2007. Changes in the global carbon cycle occurred as two episodes during the Permian-Triassic crisis. Geology 35, 10831086.

Xie, S., Pancost, R.D., Wang, Y., Yang, H., Wignall, P.B., Luo, G., Jia, C., Chen, L., 2010.

Cyanobacterial blooms tied to volcanism during the 5 my Permo-Triassic biotic crisis.

Geology 38 (5), 447-450.

Yang, H., Chen, Z.Q., Wang, Y., Tong, J., Song, H., Chen, J., 2011.

Composition and structure of microbialite ecosystems following the endPermian mass extinction in South China. Palaeogeography, Palaeoclimatology, Palaeoecology 308, 111-128.

Yang, H., Chen, Z.Q., Ou, W., 2015a. Microconchids from microbialites near the Permian-Triassic boundary in the Zuodeng Section, Baise area, Guangxi Zhuang Autonomous Region, South China and their paleoenvironmental implications. Journal of Earth Science 26 (2), 157-165.

Yang, H., Chen, Z.Q., Wang, Y., Ou, W., Liao, W., Mei, X., $2015 b$.

Palaeoecology of microconchids from microbialites near the Permian-Triassic boundary in South China. Lethaia 48, 497-508. 
Yang, S., Hao, W., Wang, X., 1999. Conodont evolutionary lineages, zonation, and P-T boundary beds in Guangxi, China: In Yao, A., Ezaki, Y., Hao W., and Wang, X., eds., Biotic and Geological Developments in the Paleo-Tethys in China. Peking University Press, Beijing, 81-95.Yin, H.F., Jiang, H.S., Xia, W.C., Feng, Q.L., Zhang, N., Shen, J., 2014. The end-Permian regression in South China and its implication on mass extinction. Earth-Science Reviews 173, 19-33.

Zaton, M., Taylop, P.D., Vinn, O., 2013. Early Triassic (Spathian) Postextinction microconchids from Western Pangea. Journal of Paleontology 87, $159-165$.

Zhang, Y., Zhang, K.X., Shi, G.R., He, W.H., Yuan, D.X., Yue, M.L., Yang, T.L., 2014. Restudy of conodont biostratigraphy of the Permian-Triassic boundary section in Zhongzhai, southwestern Guizhou Province, South China. Journal of Asian earth science 80, 75-83.

\section{Figure captions:}

Fig. 1. Tectonic map of South China and palaeogeographic map of the Nanpanjiang Basin. a, Tectonic map of South China Block including Yangtze Craton, South China fold system and the Nanpanjiang Basin (modified from 
Lehrmann et al.,1998) (LS: Lang Son Arc, SC: Song Chay suture). b, Palaeogeographic map and the locations of the studied sections in the Nanpanjiang Basin (Luolou Platform) (modified from Fan et al., 2014). A-flood alluvial facies, B-shallow-water siliciclastic deposit, C-carbonate platform, Dslope, E-basin, F-studied sections (1- Wuzhuan, 2- Nanem, 3- Tienbao, 4Youping, 5- Longyuan, 6- Shanmenhai, 7- Taiping) (GBG: Great Bank of Guizhou).

Fig. 2. Nanem and Wuzhuan PTB sections and carbonate carbon isotope data from Wuzhuan section. Numbers on the right side of each section refer to lithological units as discussed in the text: Unit 1- Bioclastic wackestonepackstone of Heshan Fm., Unit 2- Ash layer, Unit 3- Bioclastic packstonegrainstone, Unit 4- Thin layer of microbialites, Unit 5- Thin layer of ooidbioclastic packstone, Unit 6a- Stromatolite microbialite (absent in Nanem and Wuzhuan sections), Unit 6b- Thrombolite microbialite, Unit 7- Volcanogenic greywacke, Unit 8- lime mudstone. H. parvus -FO of index conodont Hindeodus parvus

Fig. 3. Shanmenhai, Taiping, Youping, Longyuan, and Tienbao PTB sections. See Fig. 2 for legend and unit numbers. The correlation line indicates the base of the Triassic (as defined by base of Unit 6). 
Fig. 4. Exposures of the studied PTB sections at a, Wuzhuan, b, Nanem, c, Tienbao.

Fig. 5. Close-up view of the boundary between Heshan and Luolou formations, Wuzhuan section. Unit numbers: see Fig. 2. Event Surface 1-5: ES1 to ES5, see explanation in text. a, Close-up view of the PTB interyal, boundaries between units are marked by black arrows. $\mathbf{b}$, Photomicrograph of the foraminifer grainstone of Unit 3. c, Photomicrograph of the contact between microbialites facies of Unit 4 and foraminifer ooid packstone of Unit 5. d, Photomicrograph of the foraminifer ooid packstone of Unit 5.

Fig. 6. Photomicrographs of marine cements and stylolites in the Wuzhuan section. a, Bioclasts coated by marine cement, Unit 3 (red arrows indicate fibrous cement). b, Bioclasts coated by marine radiaxial fibrous cement, Unit 3 . Space between coated grains filled with blocky calcite. c, Enlargement of red rectangle in Fig. 6b. d, Example of stylolite cutting across Permian grains and cements, Unit 3. e, Bioclastic grainstone of Unit3 in natural light. $\mathbf{f}$, Cathodoluminescence image of the sample illustrated in Fig 6e. Bioclastic grains display similar luminescence as cements, indicating a late diagenetic overprint. 
Fig. 7. Field photographs of domical structures in the microbialites. a, Upper part of microbialites at Tienbao section. b, Domical microbialites (dark) and a shelly lens (light) in the upper part of Wuzhuan section. $\mathbf{c}$ and $\mathbf{e}$, Upper part of Youping section. d, Upper part of Nanem section.

Fig. 8. Mesostructures of the microbialites. a, Field photograph of spotted mesostructures, Nanem section. b, Polished slab photograph of the spotted mesostructures, Nanem section. c, Polished slab of the layered mesostructure with stromatactis-type fenestral structures, Youping section. d, Field photograph of labyrinthic mesostructure, Youping section. e, Polished slab photograph of labyrinthic mesostructure, Youping section. f, Polished slab of layered vesicular mesostructure (outlined), Youping section.

Fig. 9. Photomicrographs of different structures of microbialites. a, Spotted structure, Nanem section. b, Layered structure with stromatactis-type fenestral texture, Youping section. c, Aggregated globular renalcid-group calcimicrobes (micritic-wall spherical structures) and sparite-filled cavities, Youping section. d, Labyrinthic structure, Youping section. e, Vesicular structure, Youping section. f, Digitate structure. The micritic part shows axial and equatorial sections of Cornuspira sp. (= Postcladella Krainer and Vachard, 2011), Tienbao section. 
Fig. 10. Close-up view of the boundary between Heshan and Luolou formations, Nanem section. Unit numbers: see caption of Fig.2. Event Surface 1-5: ES1 to ES5, see explanation in text. a, Close-up view of the PTB interval, boundaries between units are marked by black arrows. $\mathbf{b}$, Polished slab of the contacts between Units 3, 4 and 5. Note the erosional lower and upper limits (ES3 and ES4) of stromatolites (Unit 4).

Fig. 11. Photographs of the contact between skeletal limestones and microbialites at Nanem, Longyuan and Tienbao sections. a and b, Polished slabs of the contact at Nanem section, red arrows show undulating surface with iron oxide crust. c, Photomicrographic enlargement of the red rectangle in Fig. $11 \mathrm{~b}$ showing the millimetric lamination of a stromatolite. d, Polished slabs of the contact at Longyuan section showing the contact between the skeletal grainstone of Unit 3 and the stromatolite of Unit 6a. e, Photomicrographic enlargement of the red rectangle in Fig. 11d, showing the sharp contact between Units 3 and 6a. f, Photomicrographic enlargement of the red rectangle area in Fig. 11e showing the upper truncation of the bioclasts (mainly foraminifers, calcareous algae, crinoids) of Unit 3. g, Polished slab of the contact between Units 3 and 6a, Tienbao section. Note the growth of stromatolite (dark) atop of the erosional upper limit of the packstone. Note iron oxide remains and undulating irregular relief. $\mathbf{h}$, Close-up view of the high relief contact between Units 3 and 6a, Tienbao section. The top of Unit 3 shows patches of iron oxide. 
i, Photomicrographic enlargement of the red rectangle of Fig. 11h. The dark central protuberance belongs to Unit 3 . The light coloured left and right parts are recrystallized stromatolite of Unit 6a. Note burrows cutting across Unit 3.

Fig. 12. Photomicrographs of limestones associated with microbialites. a, Millimetric calcite fan in Unit 4, Nanem section. b, Ooid grainstone, Unit 5, Nanem section. c, Enlargement of the red rectangle in Fig. 12b, showing superficial ooid grainstone, Nanem section. d, The interstitial skeletal-rich sediment between stromatolite columns, Tienbao section. The light coloured right part is a stromatolite of Unit 6a. e, Ammonoid-bearing wackestonepackstone on top of microbialites, Unit 8, Youping section. f, Bioclastic grainstone (including, foraminifers, calcareous algae, crinoids, ostracods and bivalves) directly overlain by microbialites, Unit 3, Taiping section.

Fig. 13. Close-up view of the boundary between Heshan and Luolou formations, Tienbao section. Unit numbers: see caption of Fig. 2. Event Surface 1-5: ES1 to ES5, (ES3-ES4 are missing here) see explanation in text. Boundaries between units are marked by black arrows and dashed white lines.

Fig. 14. Digitate microbialites in upper part of Teinbao section a, Field photograph and $\mathbf{b}$, polished slab photograph. $\mathbf{c}$, Contact between the microbialites and base of the overlying Unit 7 (note the sharp contact). d, 
Vertical growth and burial of dendrolites (Unit 6b) within the overlying wackestone (intercalated between Units $6 b$ and 7).

Fig. 15. Close-up view of the boundary between Heshan and Luolou formations, Youping section. Unit numbers: see caption of Fig. 2. Event Surface 1-5: ES1 to ES5 (ES3 and ES4 are missing here) see explanation in text. Boundaries between units are marked by black arrows and dashed white lines.

Fig. 16. Close-up view of the boundary between Heshan and Luolou formations, Longyuan section. Unit numbers: see caption of Fig. 2. Event Surface 1-5: ES1 to ES5 (ES3 and ES4 are missing here) see explanation in text. Boundaries between units are marked by black arrows and dashed white lines.

Fig. 17. Close-up view of the boundary between Heshan and Luolou formations, Taiping section. Unit numbers: see caption of Fig. 2. Event Surface 1-5: ES1 to ES5 (ES3 and ES4 absent) see explanation in text. Boundaries between units are marked by black arrows and dashed white lines. Note the cross-beddings in Unit 3.

Fig. 18. Correlations of the Event Surfaces (ES) at the boundary between Heshan and Luolou formations. See text for description of Event Surfaces. 
Fig. 19. Reconstruction of the spatial relations between basal Early Triassic depositional environments in the Nanpanjiang Basin. Downthrown blocks are characterized by the deep water stratigraphic succession including the latest Permian Dalong Fm. and Early Triassic Ziyun Fm. Upthrown blocks typically display a shallow water succession comprising the latest Permian Heshan Fm. and the basal Early Triassic microbialites of the Luolou Fm. The main structuration phase of the Nanpanjiang pull-apart basin occurred around the Wujiangpingian-Changsinghian boundary and is manifested by thick wedges of synsedimentary breccias along the footwalls of uplifted blocks (not shown in this reconstruction). 

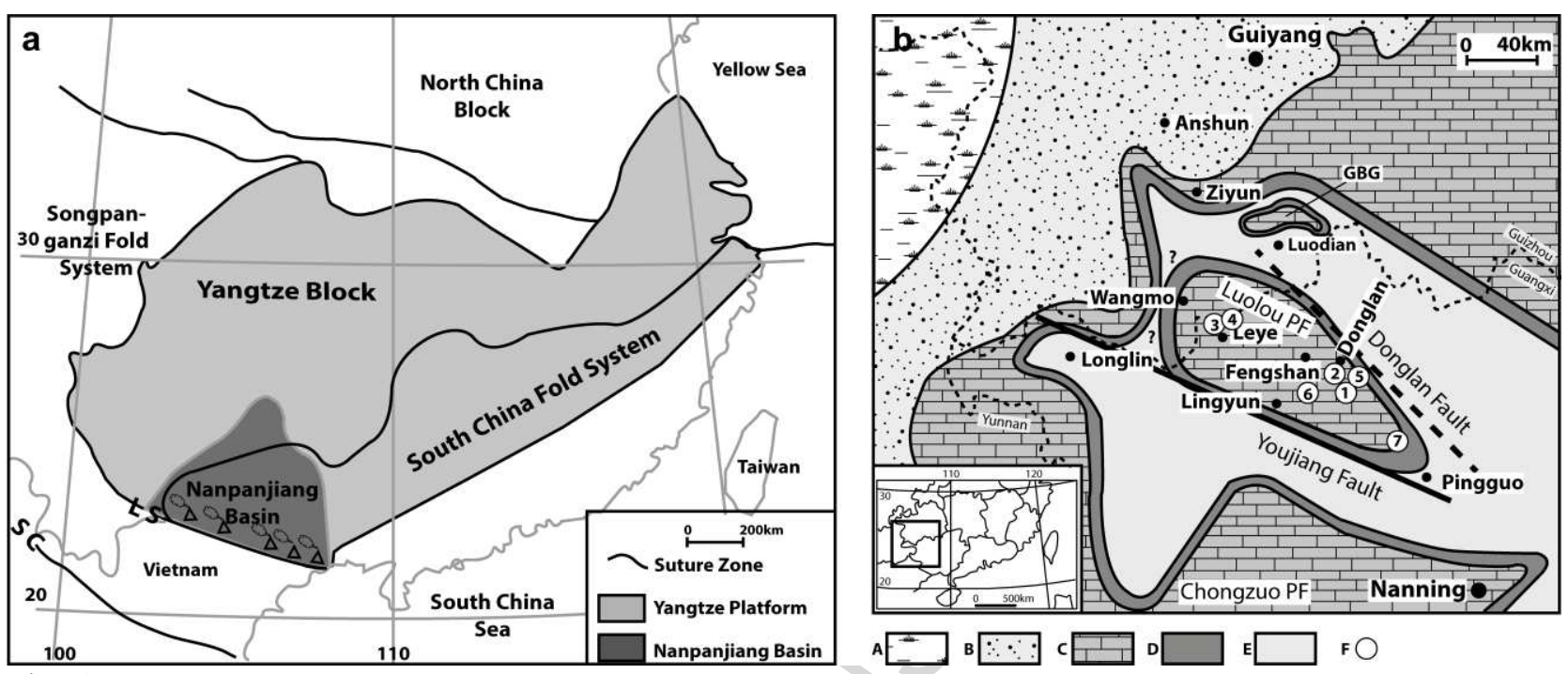

Fig. 1 


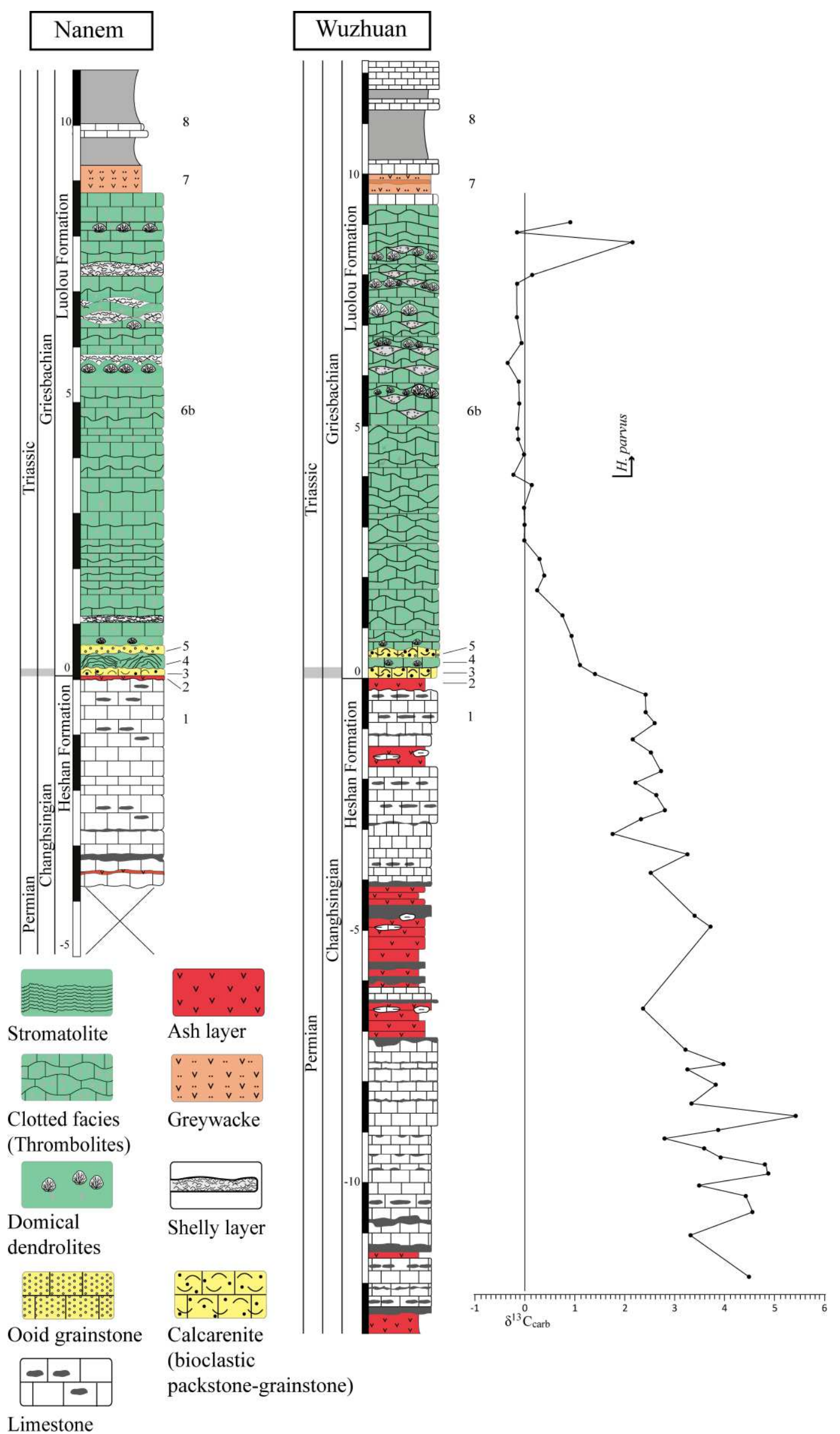

Fig. 2 


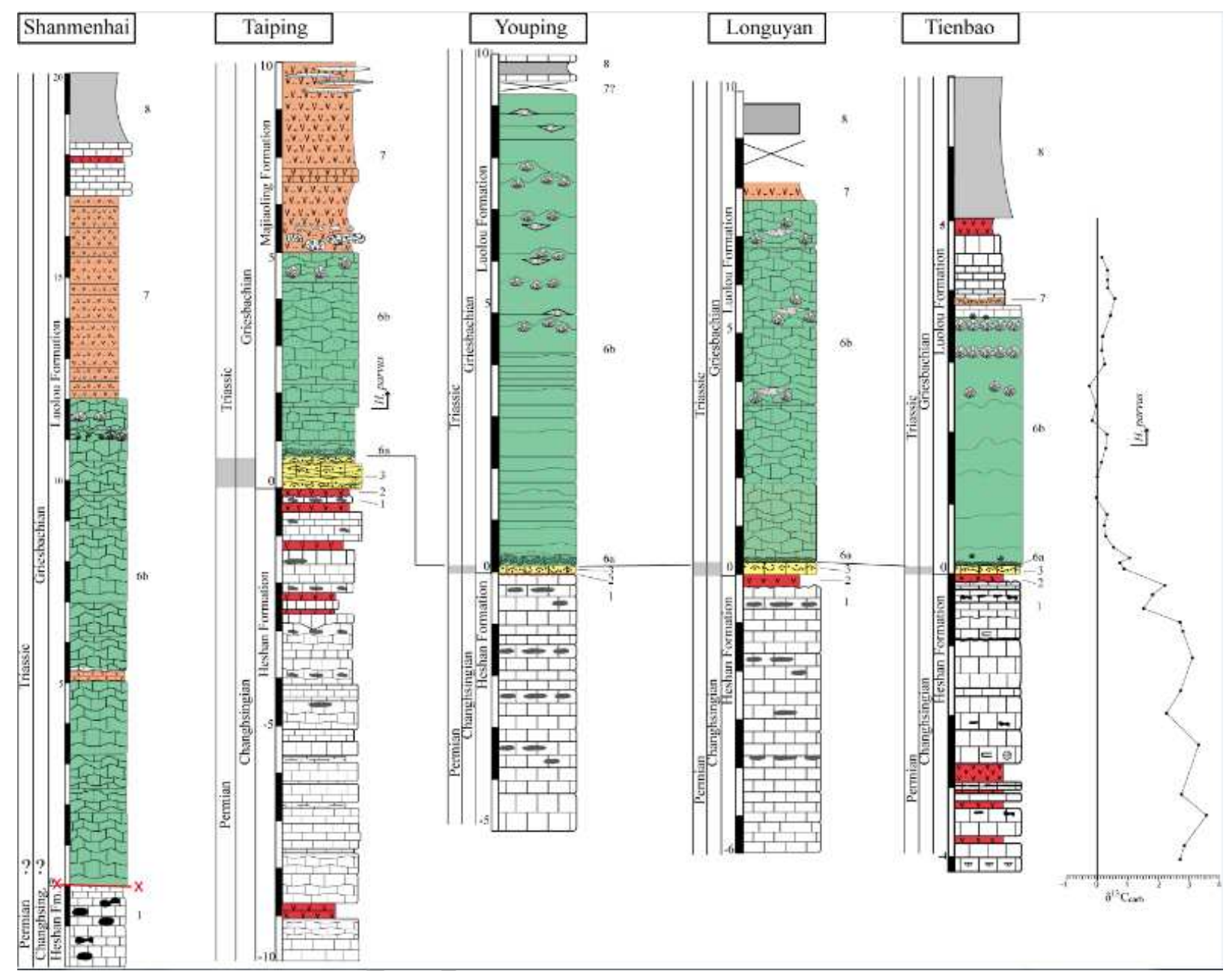

Fig. 3 

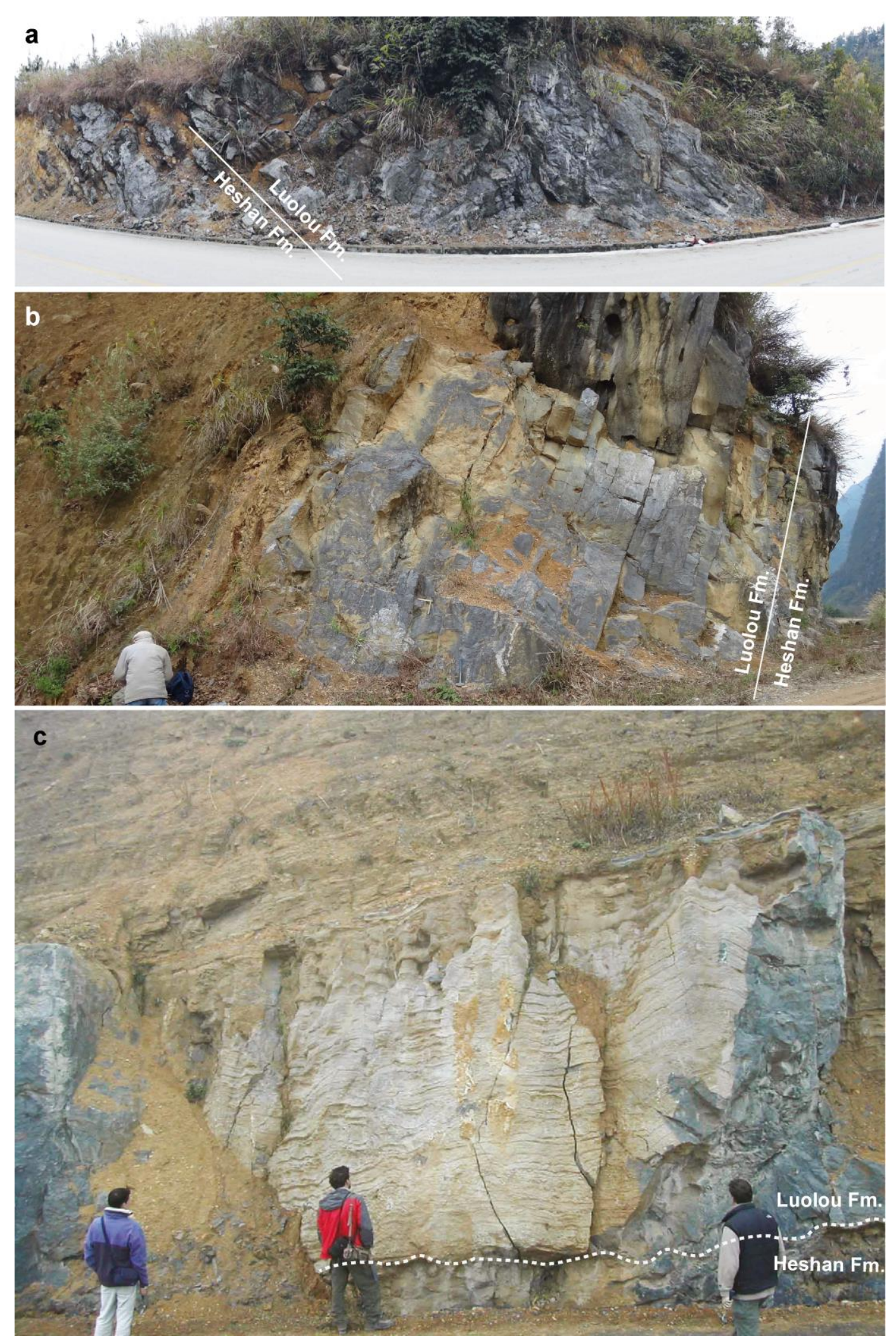

Fig. 4 


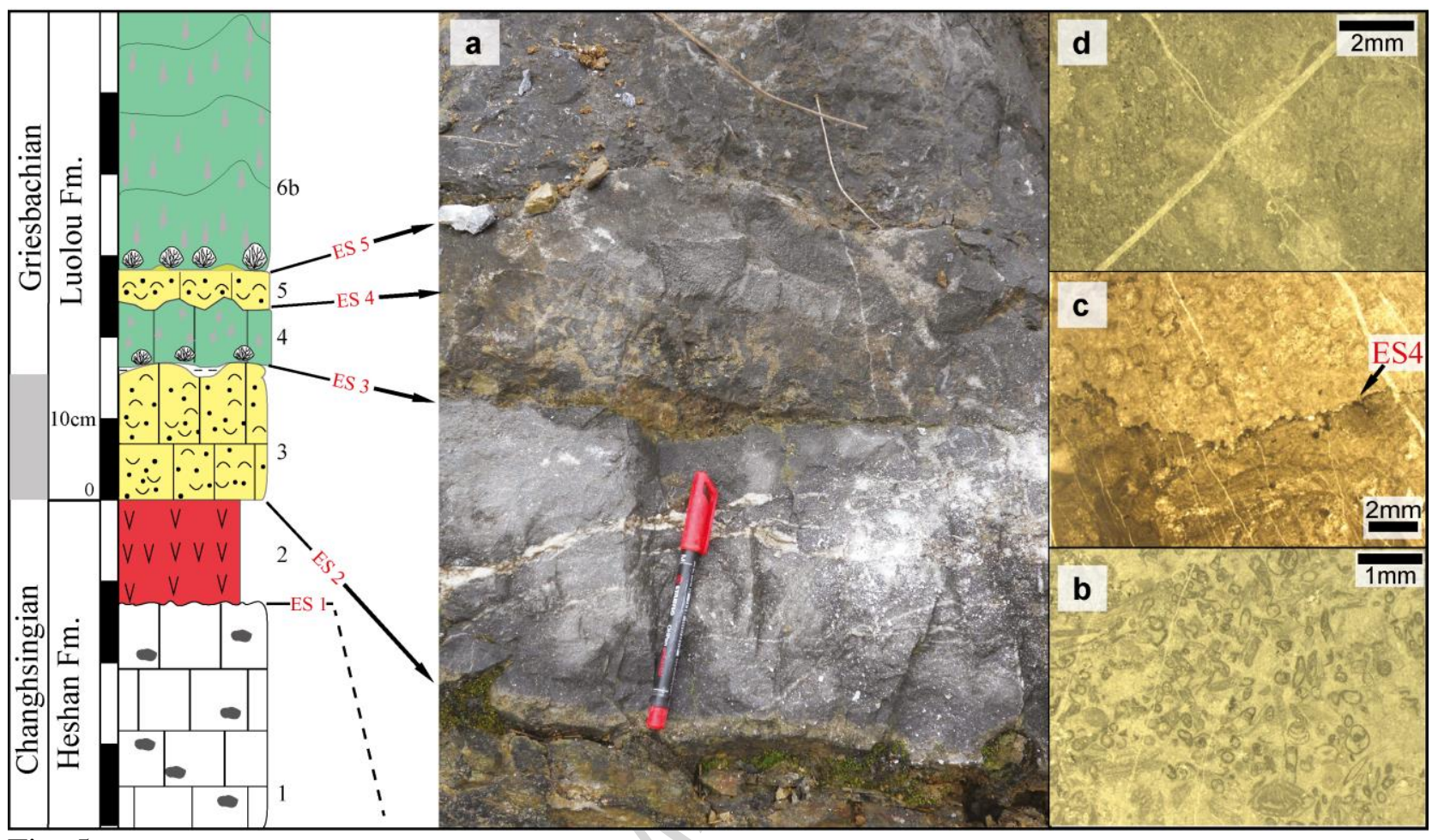

Fig. 5 

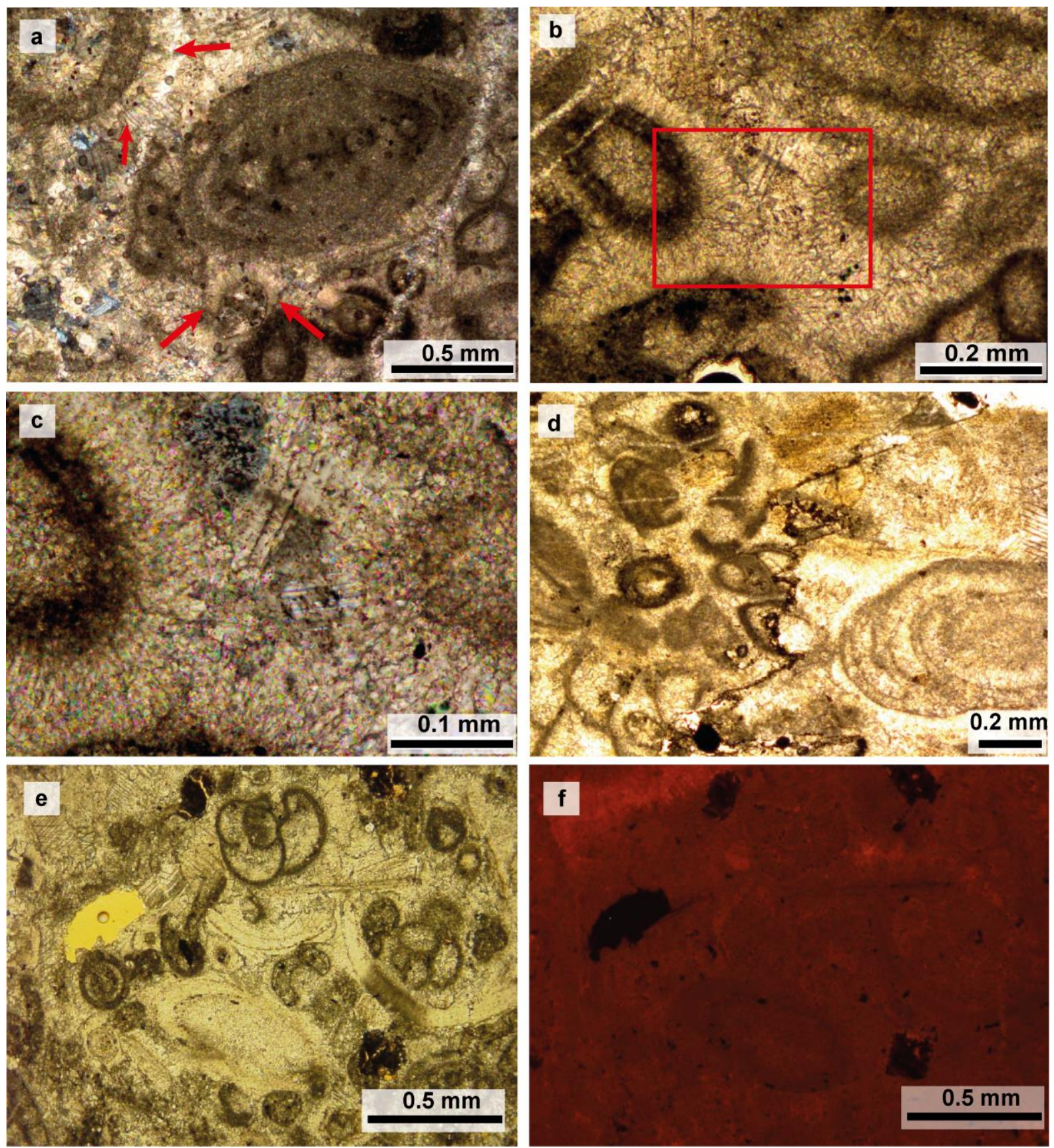

Fig. 6 

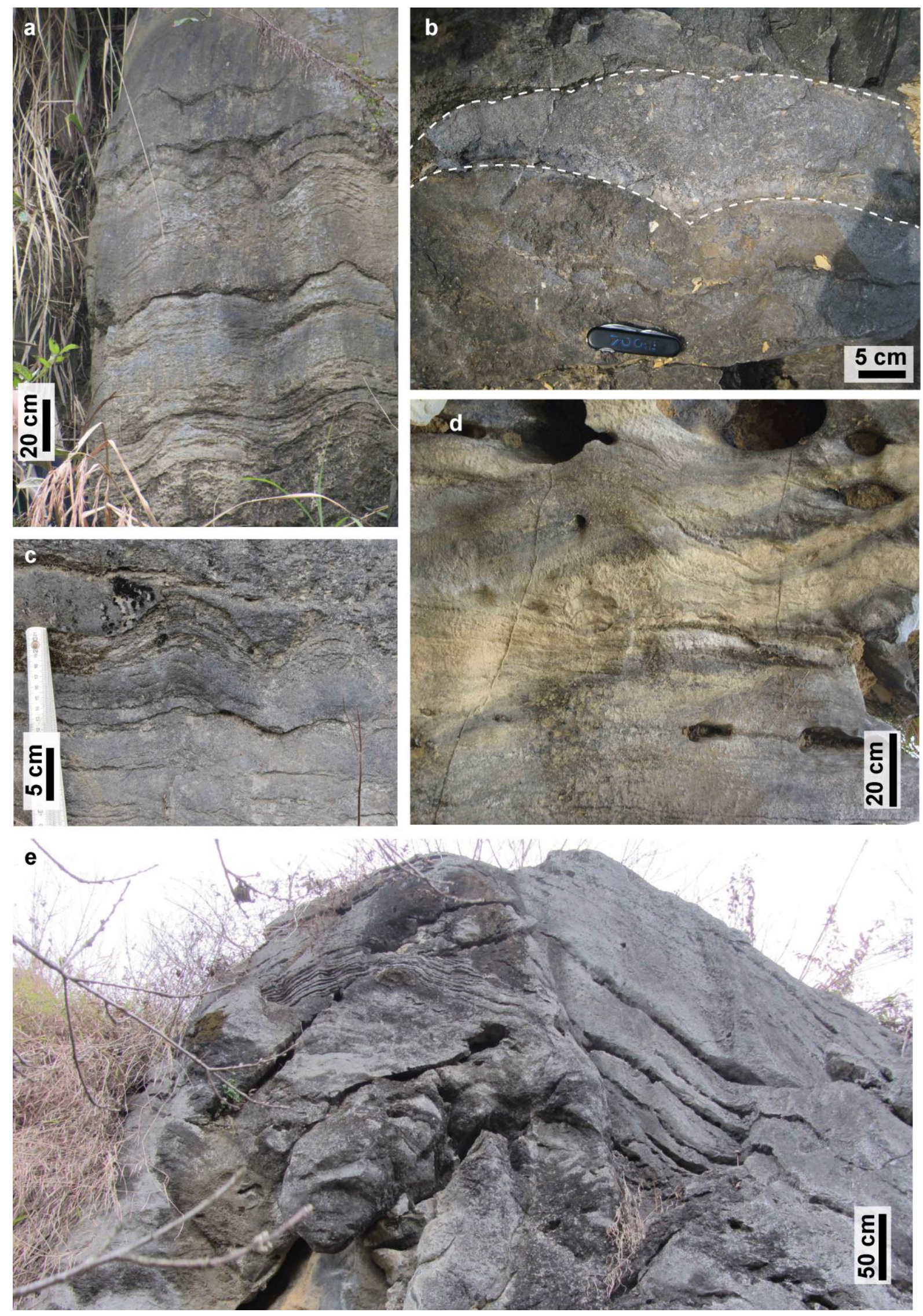

Fig. 7 

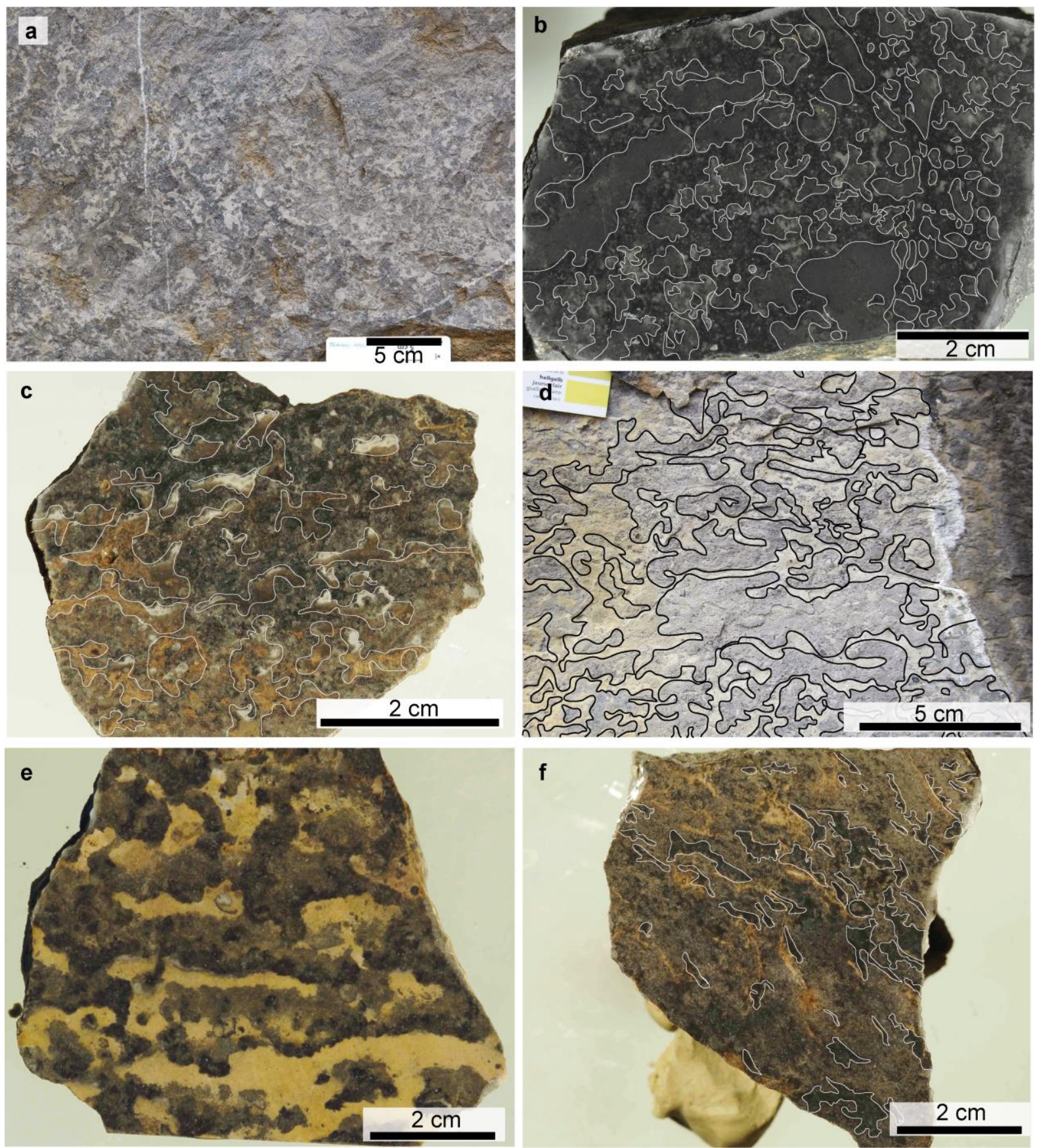

Fig. 8 

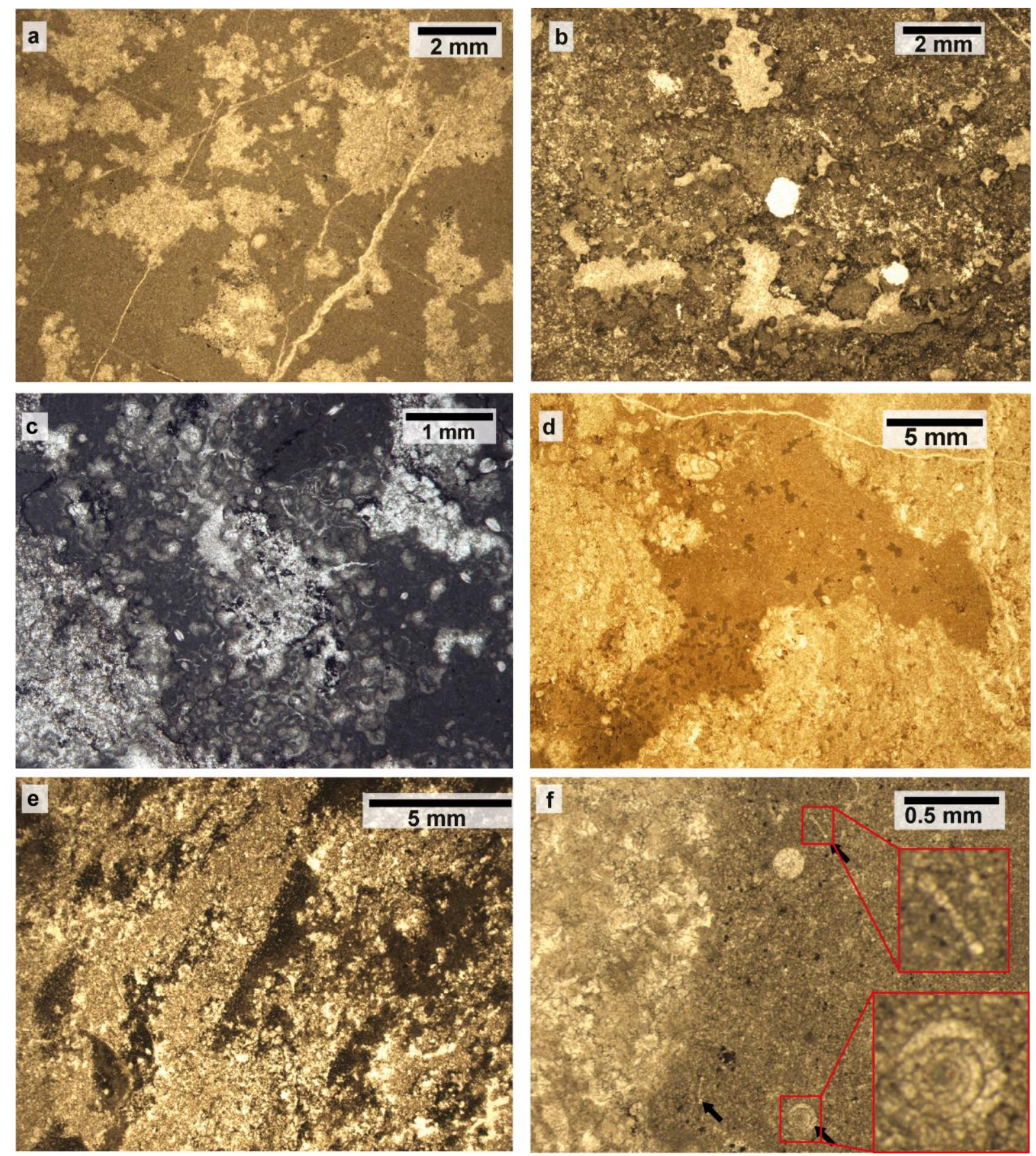

Fig. 9 


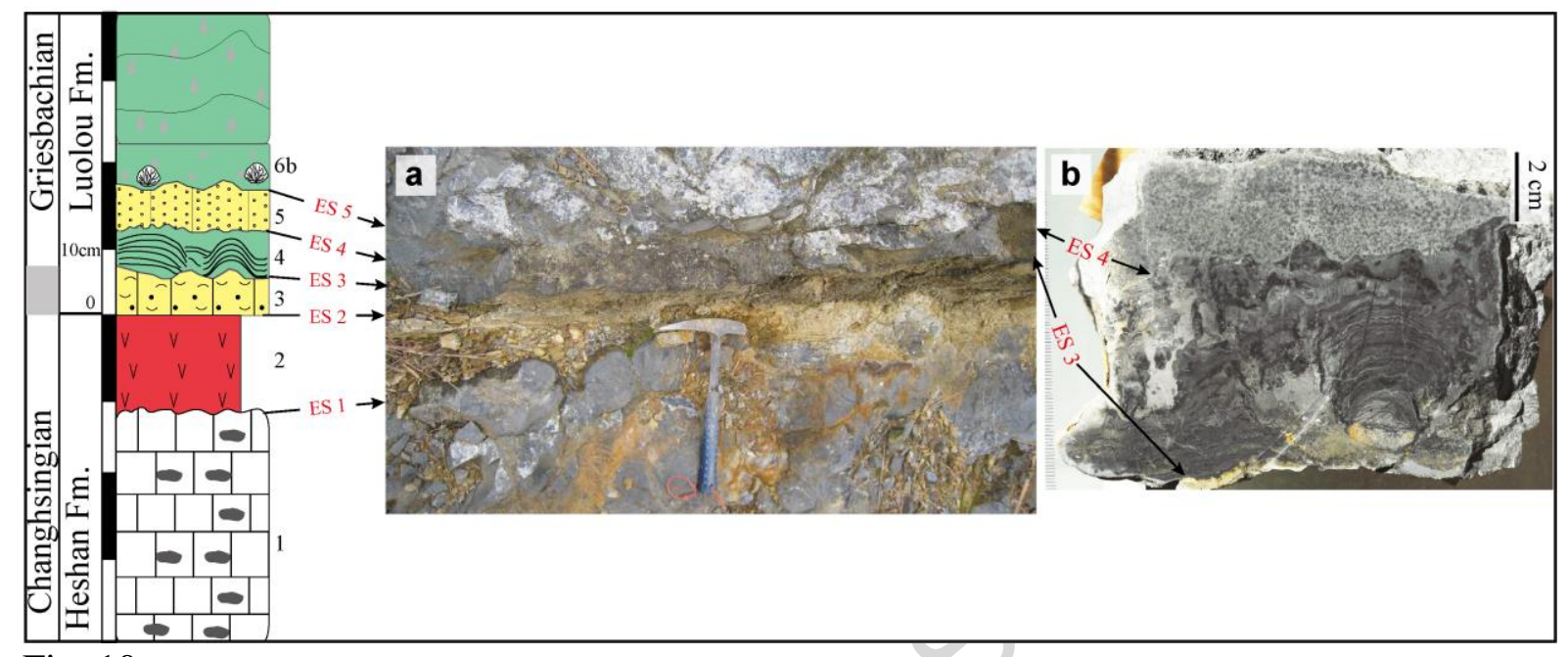

Fig. 10 

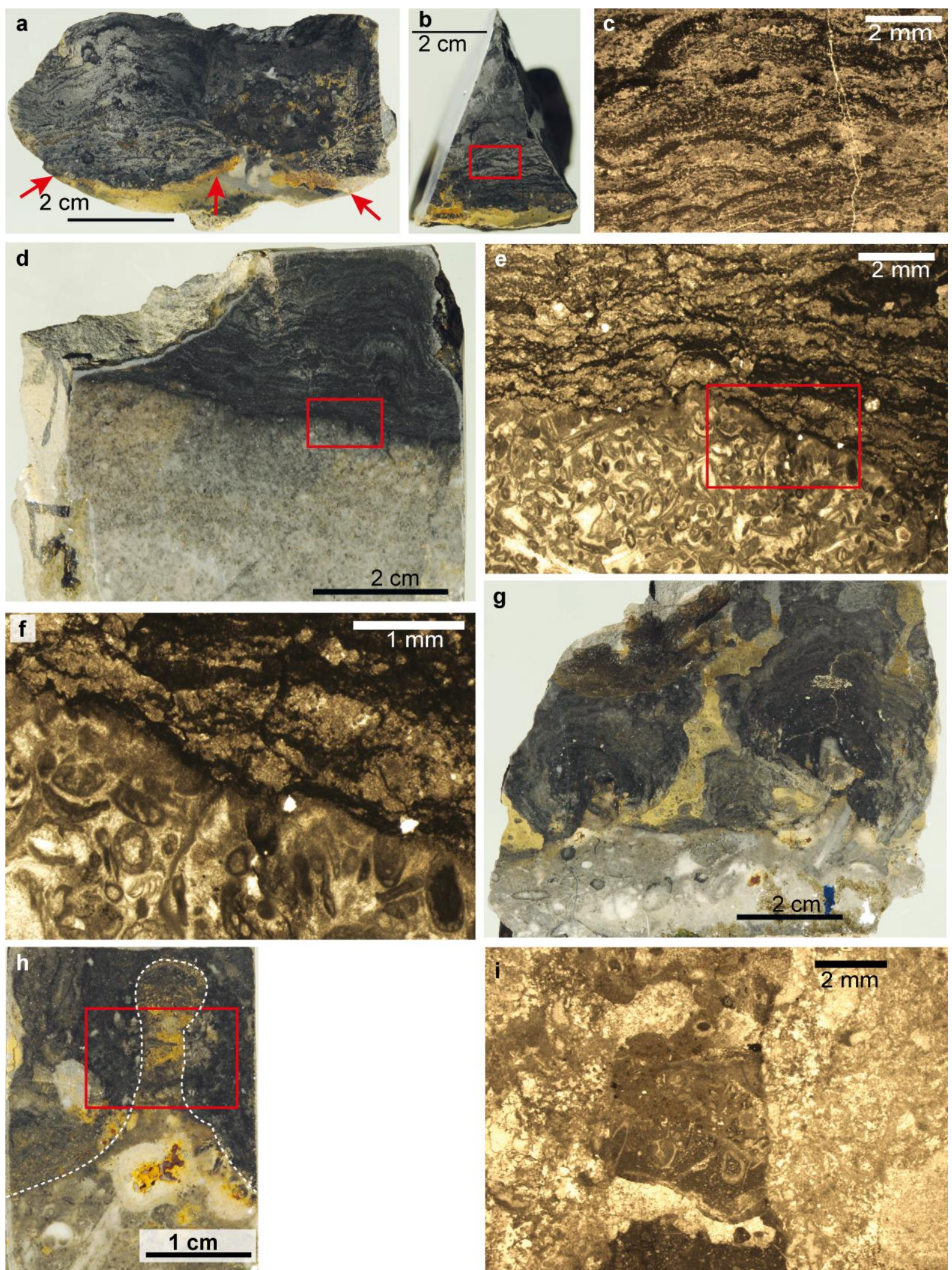

Fig. 11

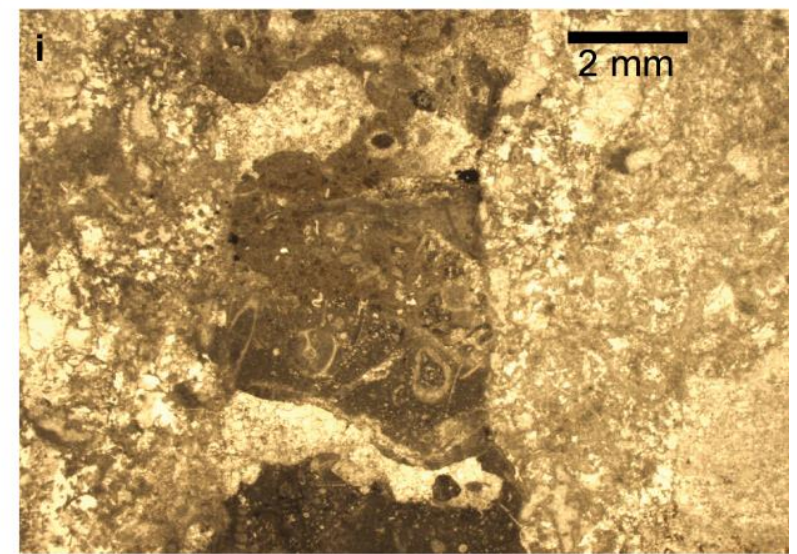



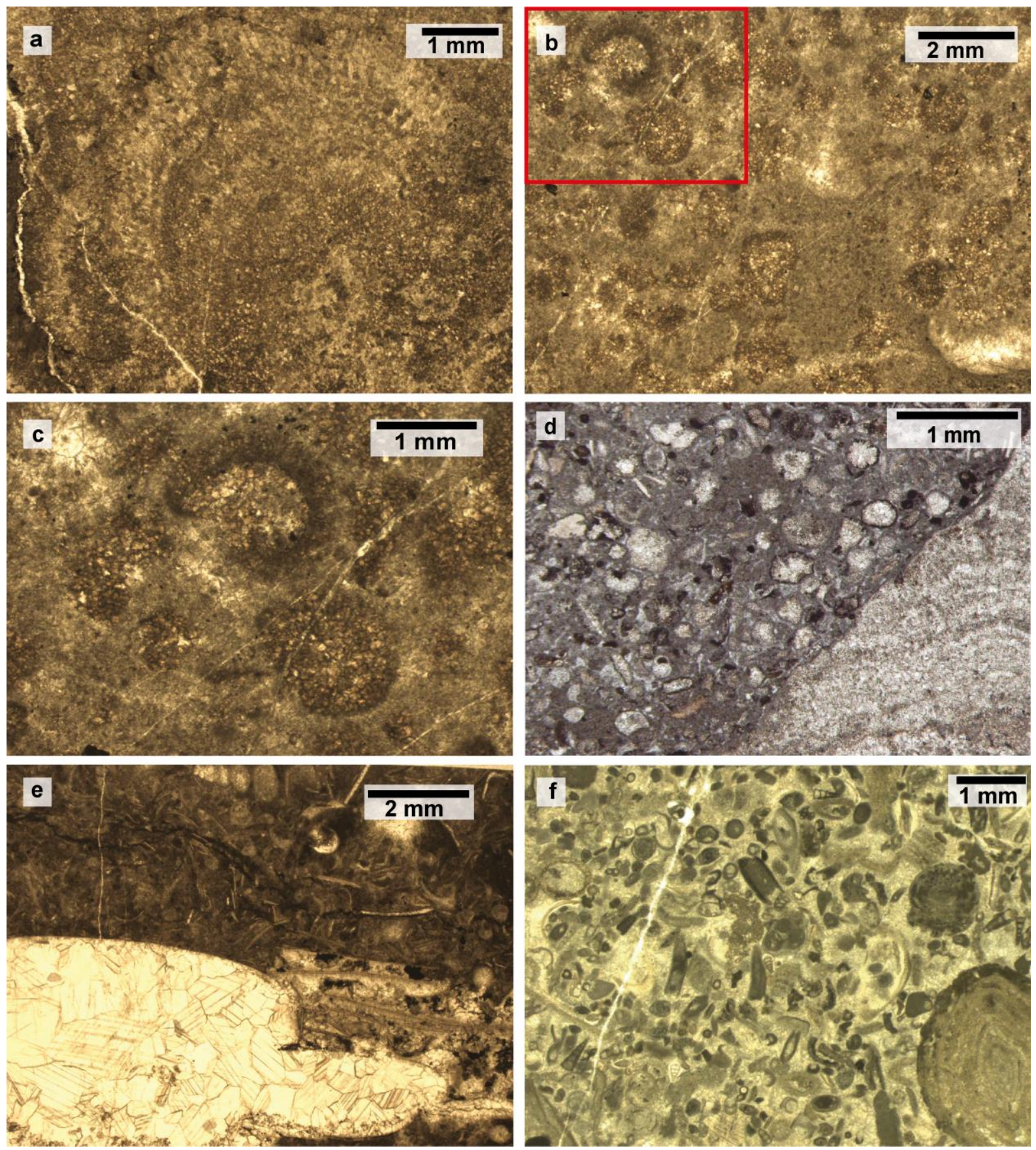

Fig. 12 


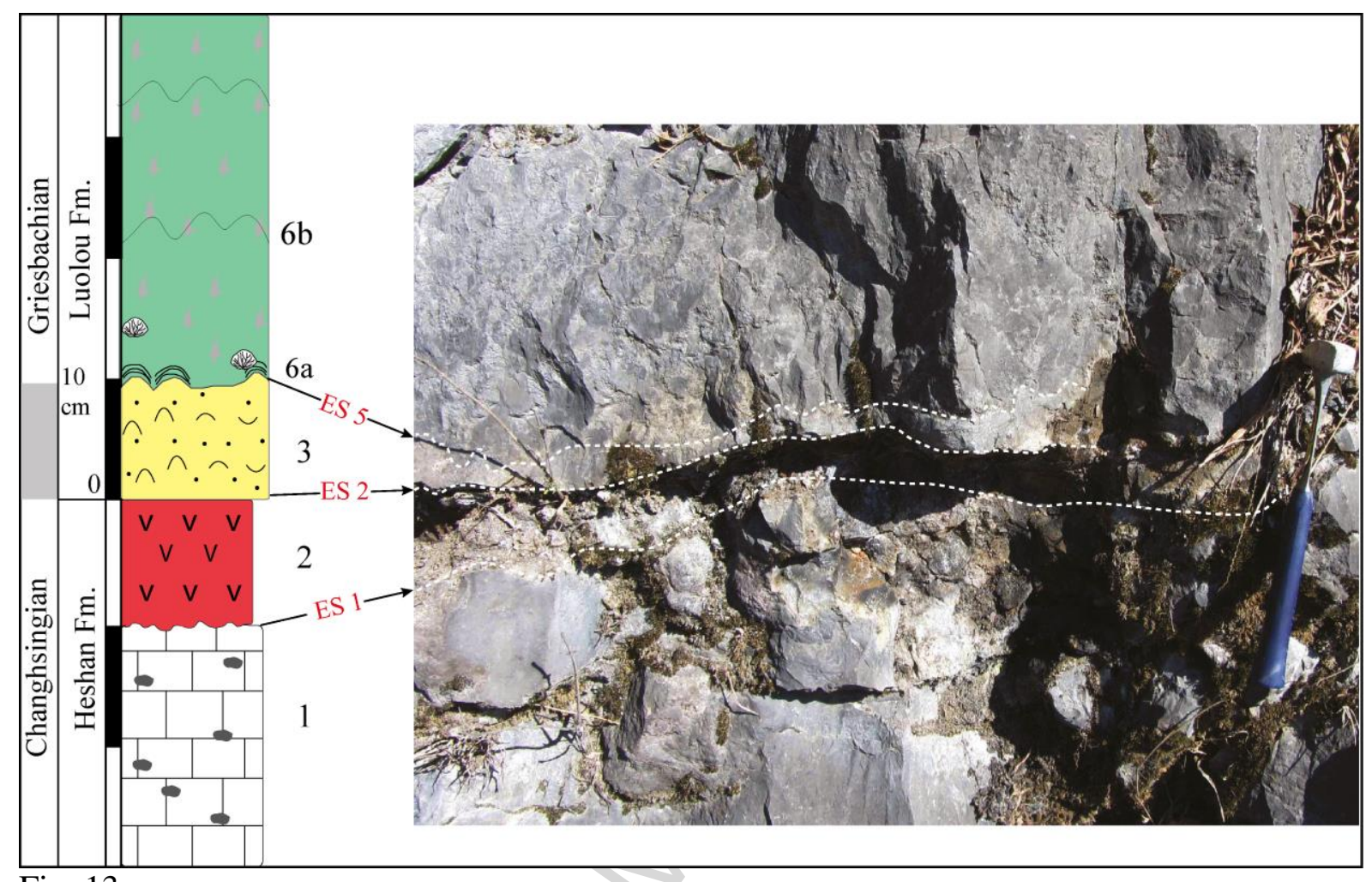

Fig. 13 

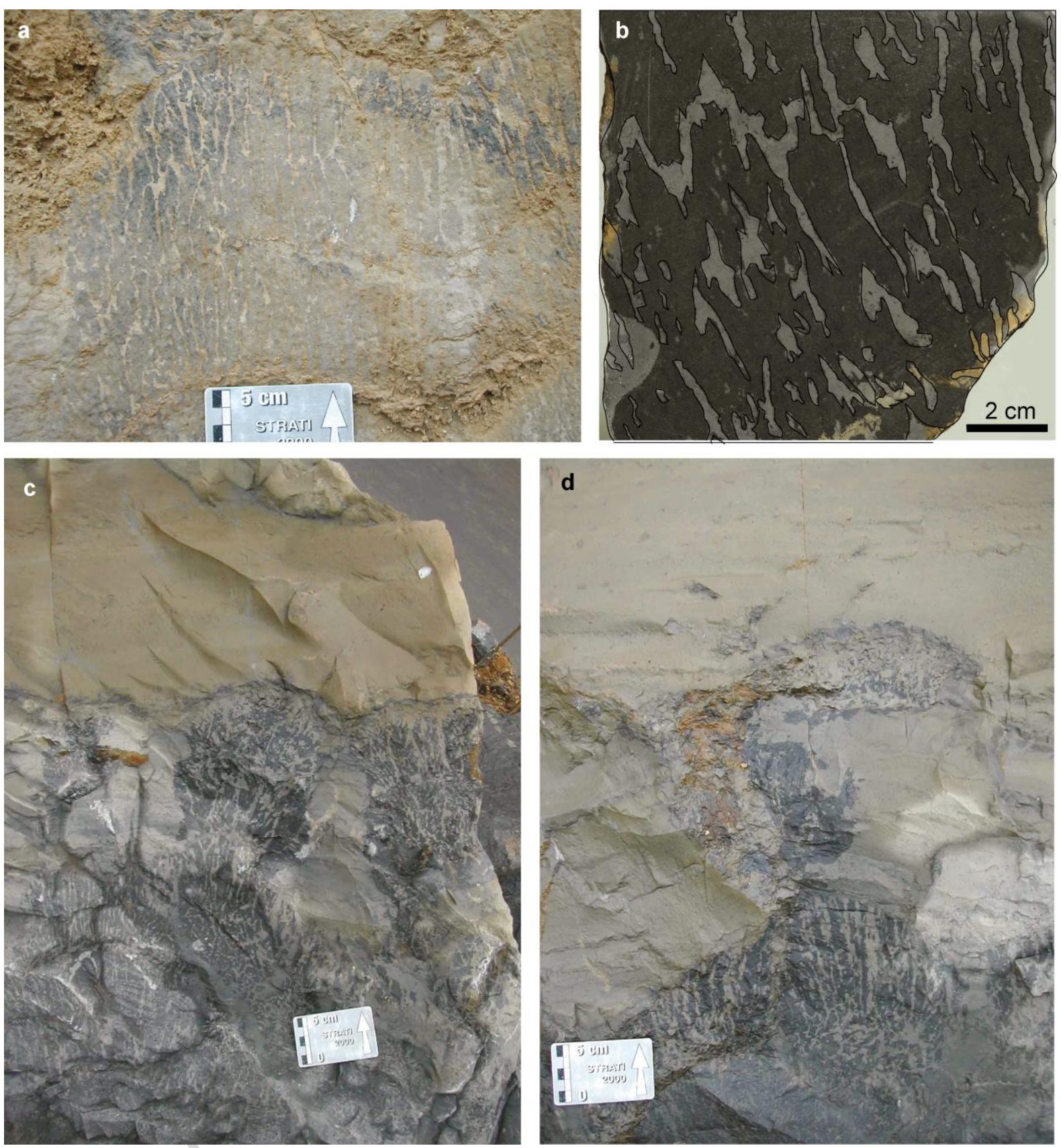

Fig. 14 


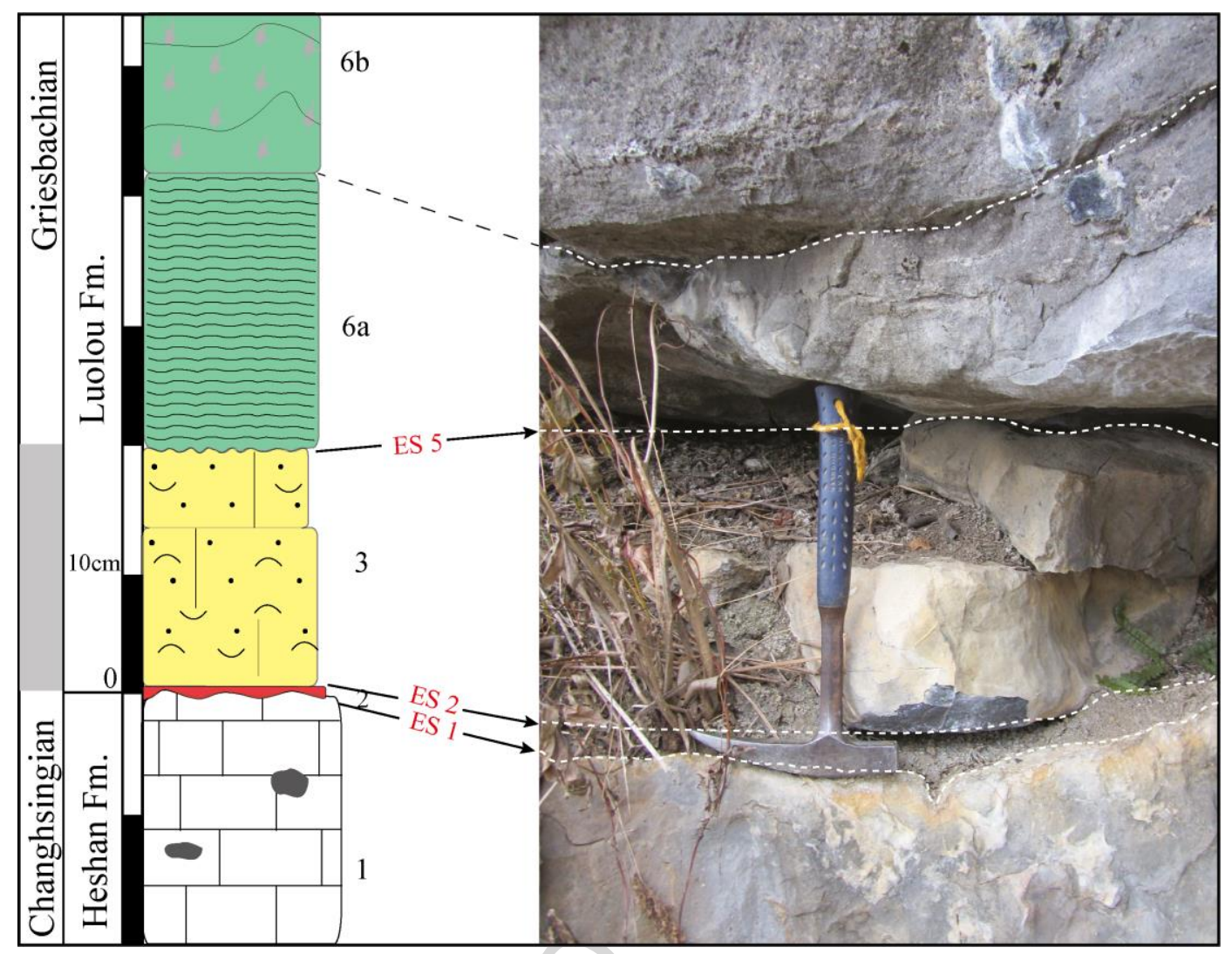

Fig. 15 


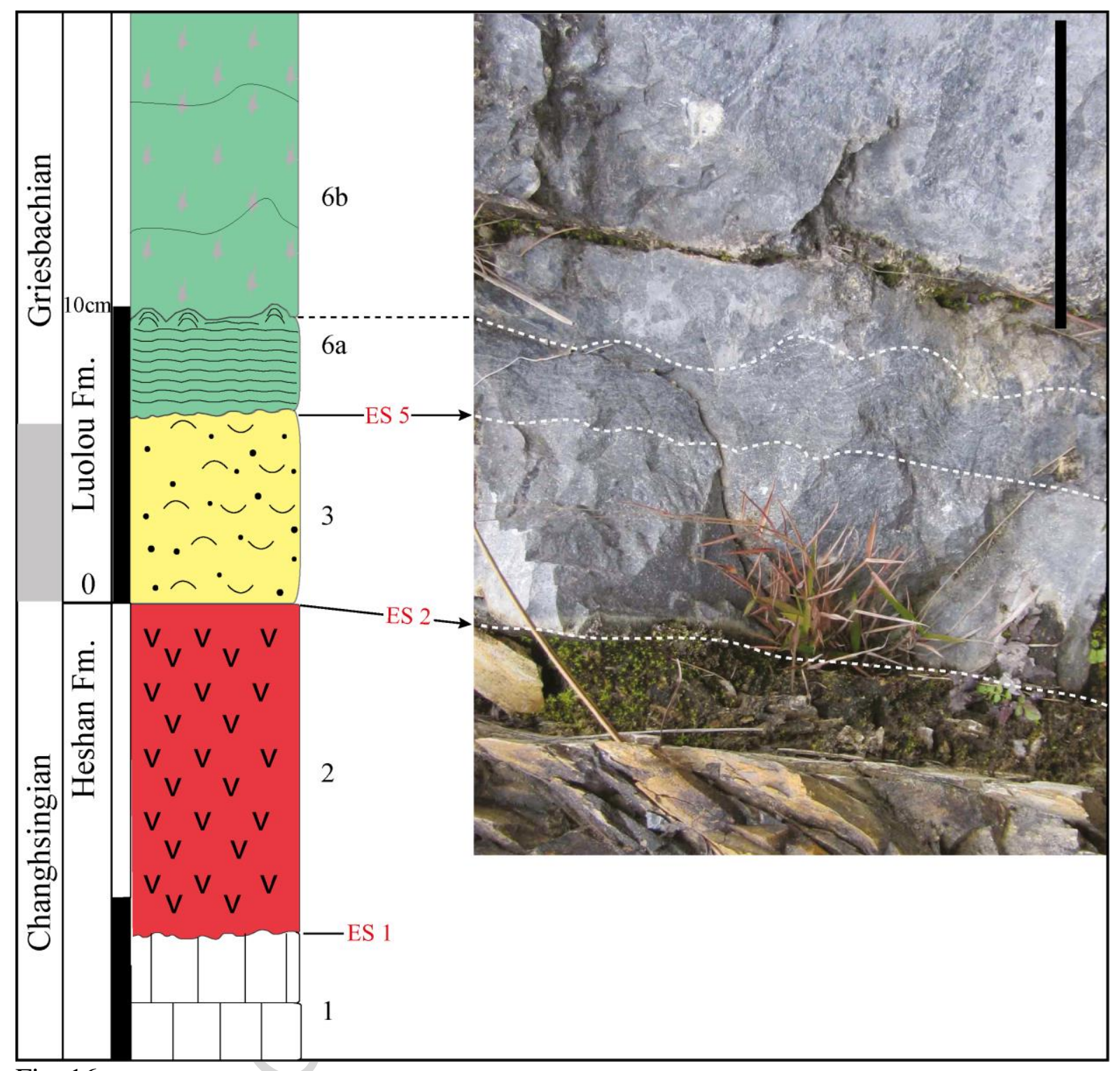

Fig. 16 


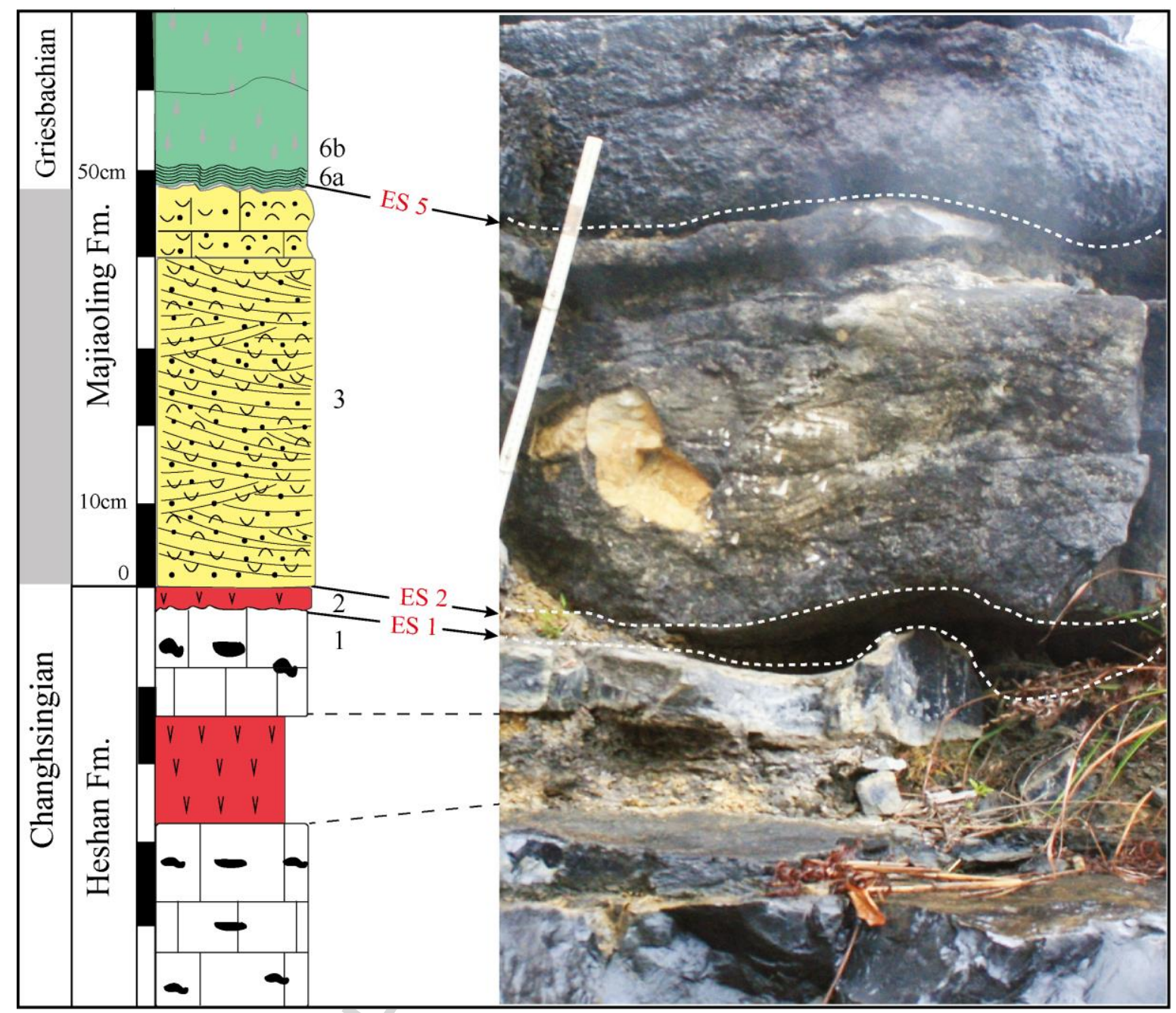

Fig. 17

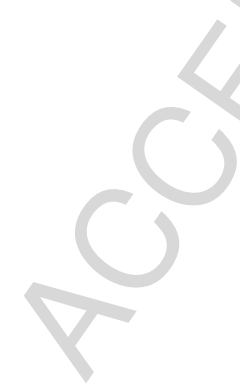




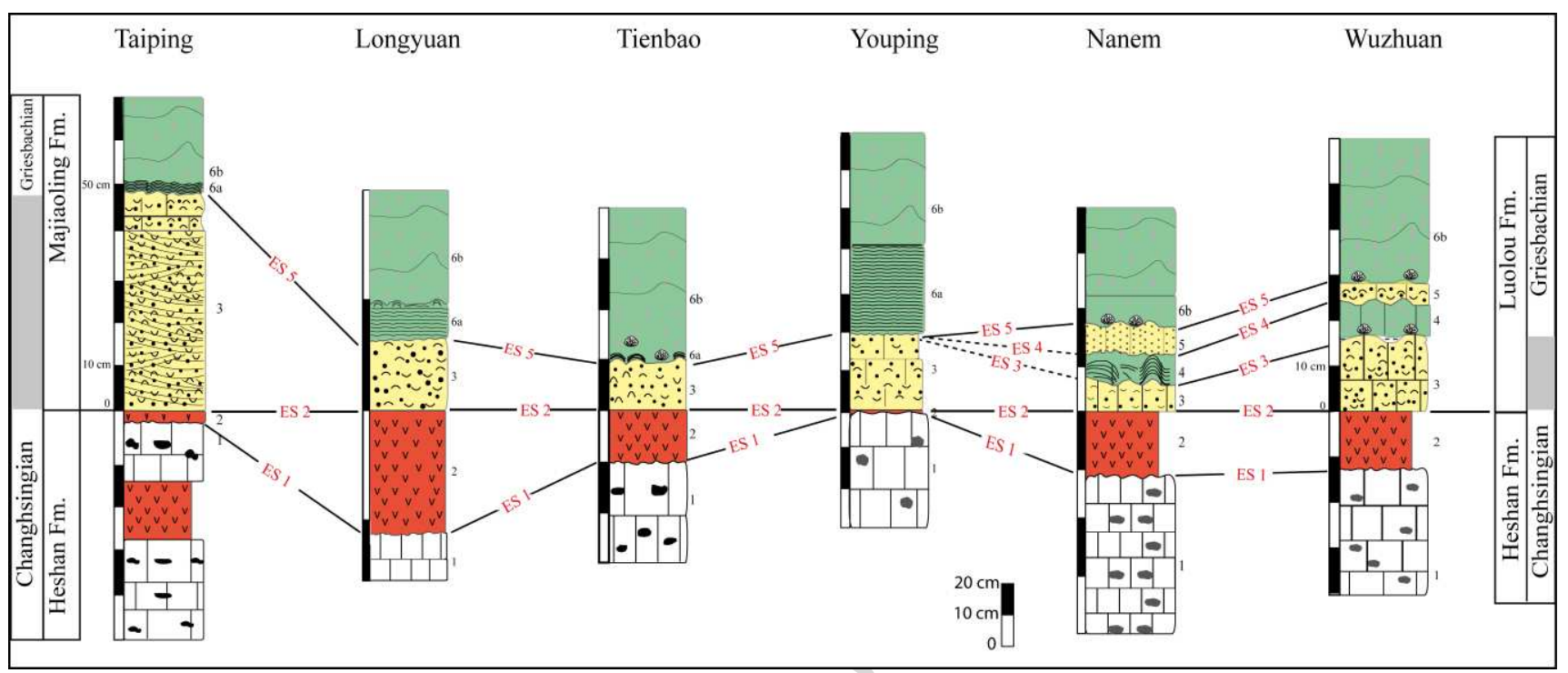

Fig. 18 


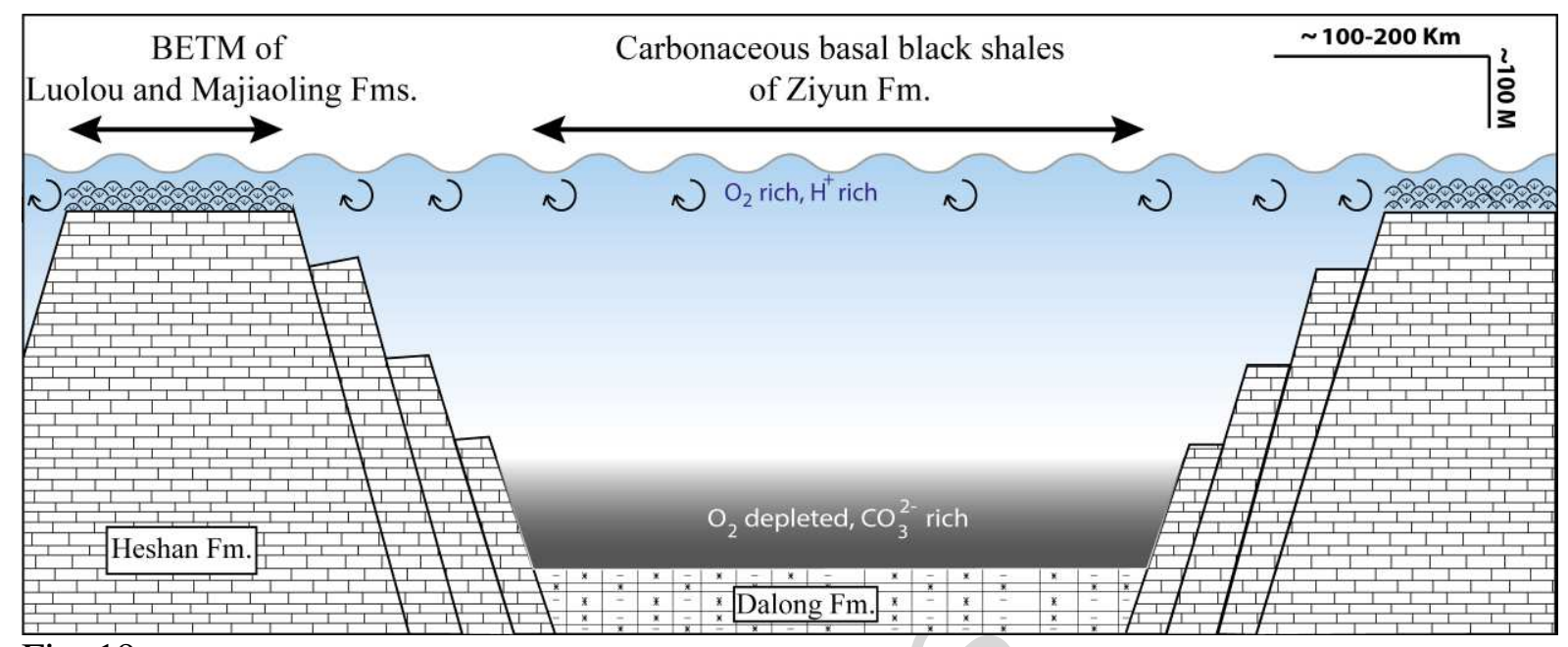

Fig. 19 


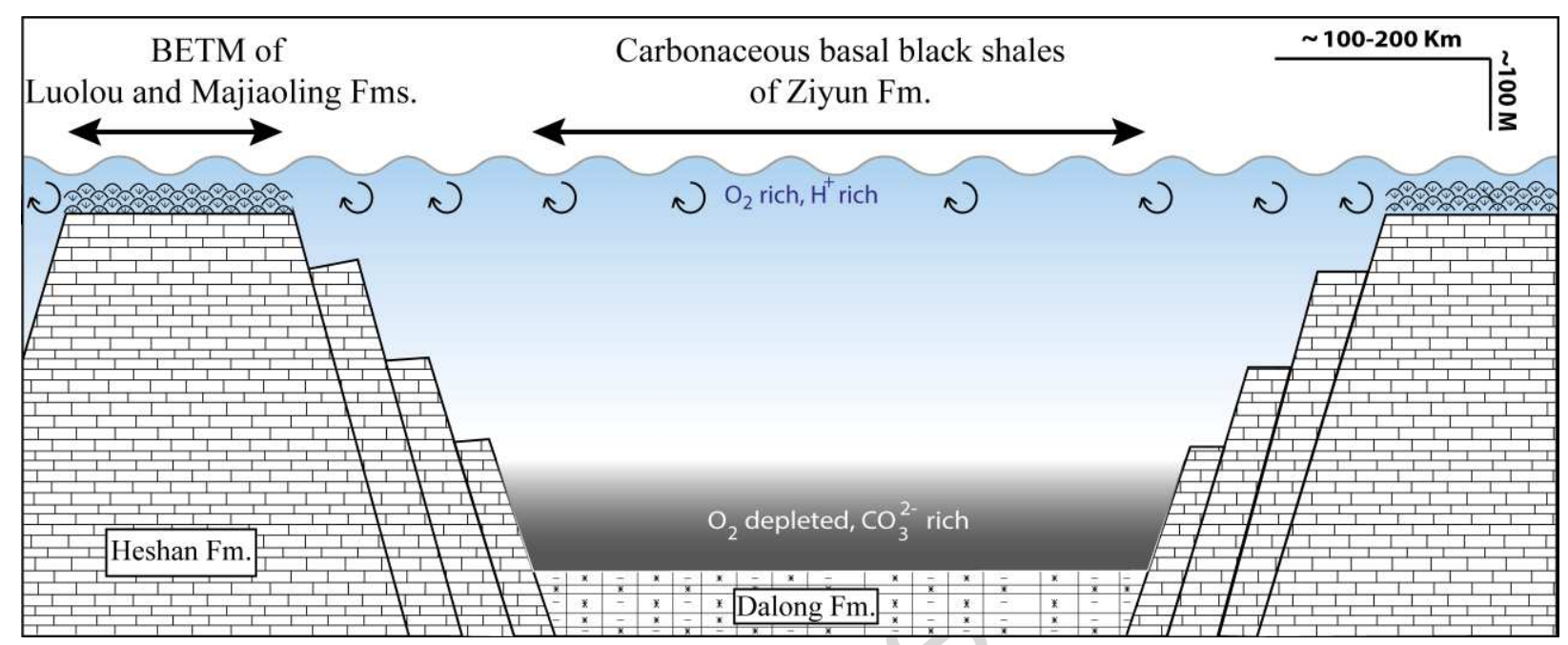

Graphical abstract 


\section{Highlights}

- BETM growth was controlled by depth, $\left[\mathrm{CaCO}_{3}\right],\left[\mathrm{O}_{2}\right], \mathrm{pH}$ and clastic load

- Occurrence of BETM is restricted to uplifted, fault bounded blocks

- BETM overly the PTB gap caused by chemical dissolution and mechanical erosion 